\title{
Corps
}

ㅇ crigineers

Waterways Experiment

Station

\section{Sediment Impact Assessment, Manitou Springs, Colorado}

by Ronald R. Copeland, Lisa C. Hubbard

Approved For Public Release; Distribution Is Unlimited 


\section{Sediment Impact Assessment, Manitou Springs, Colorado}

by Ronald R. Copeland, Lisa C. Hubbard

U.S. Army Corps of Engineers

Waterways Experiment Station

3909 Halls Ferry Road

Vicksburg, MS 39180-6199

Final report

Approved for public release; distribution is unlimited

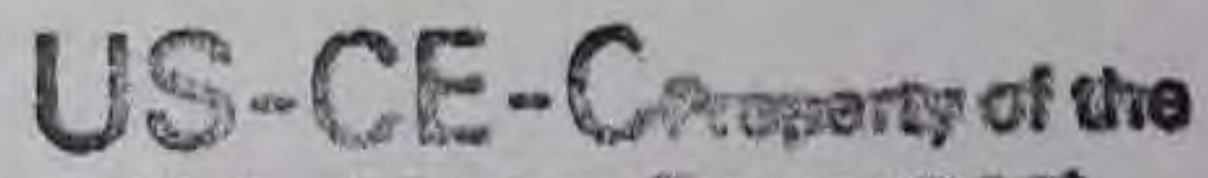
United Sistos Genervinent

RESEARCH LIBRARY

USARMY ENGINEER WATERWAYS

EXPERIMENT STATION

VICKSBURG, MISSISSIPPI 


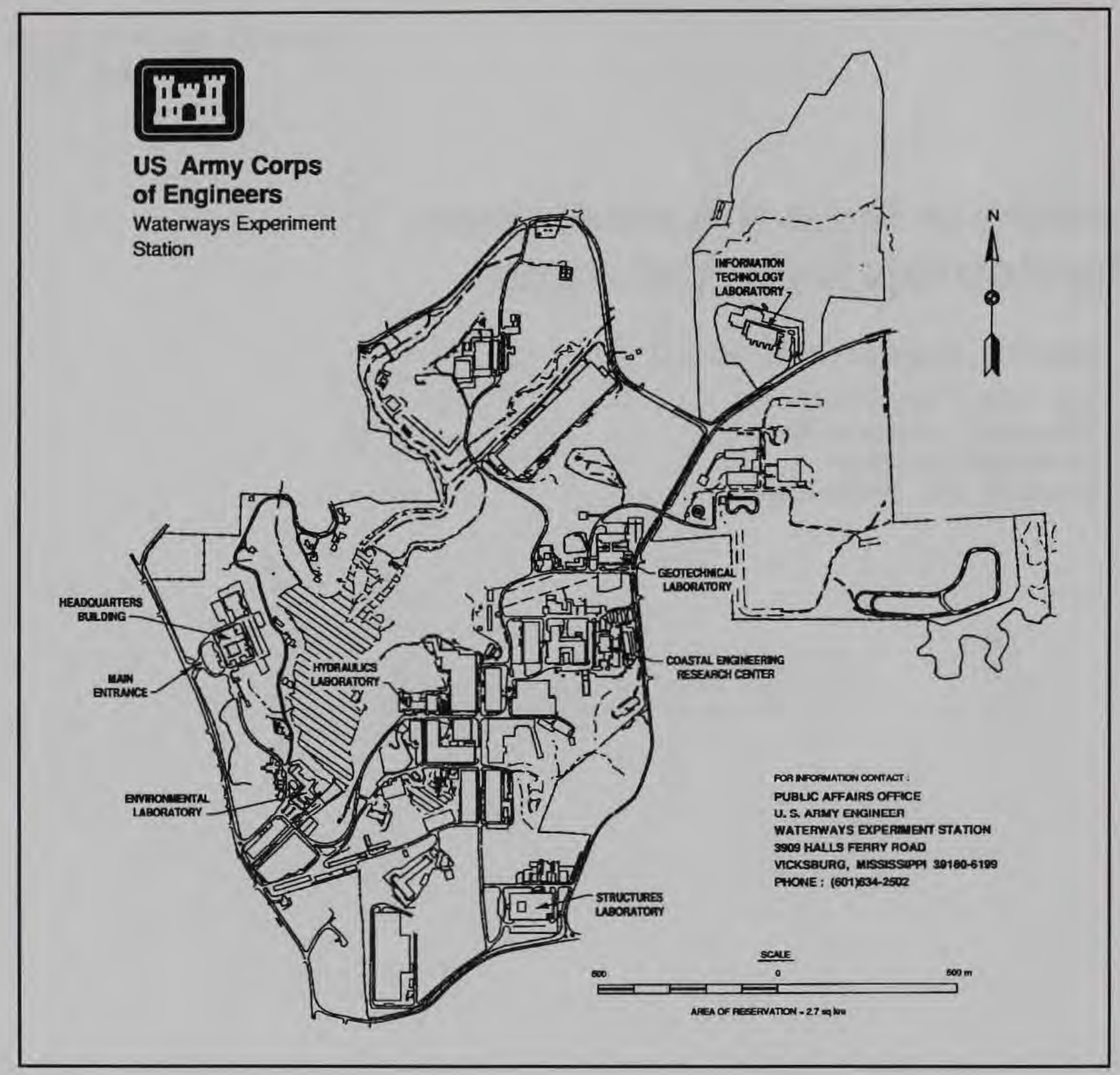

Waterways Experiment Station Cataloging-in-Publication Data

Copeland, Ronald R.

Sediment impact assessment, Manitou Springs, Colorado / by Ronald

R. Copeland, Lisa C. Hubbard; prepared for U.S. Army Engineer

District, Albuquerque.

62 p. : ill. ; $28 \mathrm{~cm}$. - (Technical report ; HL-95-3)

1. Stream channelization - Colorado - Manitou Springs.

2. Sedimentation and deposition - Colorado - Manitou Springs.

3. Flood control - Colorado - Manitou Springs. I. Hubbard, Lisa C.

II. United States. Army. Corps of Engineers. Albuquerque District.

III. U.S. Army Engineer Waterways Experiment Station. IV. Hydraulics

Laboratory (U.S. Army Engineer Waterways Experiment Station)

V. Title. V. Series: Technical report (U.S. Army Engineer Waterways

Experiment Station); HL-95-3.

TA7 W34 no. HL-95-3 


\section{Contents}

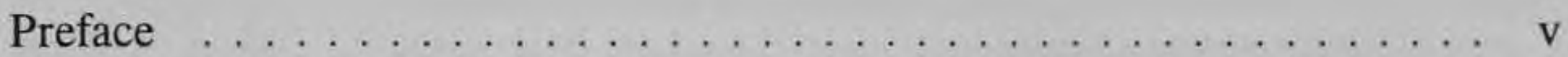

Conversion Factors, Non-SI to SI Units of Measurements . . . . . . . . vi

1 -Introduction $\ldots \ldots \ldots \ldots \ldots \ldots \ldots \ldots \ldots \ldots \ldots$

Location . . . . . . . . . . . . . . . . . . . . . . 1

Watershed Characteristics ................. 1

Valley and Streambed Characteristics . . . . . . . . . . . . 4

Climate and Precipitation .................. 5

Purpose of the Study . . . . . . . . . . . . . . . 5

Approach .................... 6

2-Channel Stability $\ldots \ldots \ldots \ldots \ldots \ldots \ldots \ldots \ldots \ldots \ldots \ldots$

Channel Geometry $\ldots \ldots \ldots \ldots \ldots \ldots \ldots \ldots \ldots \ldots$

Hydraulic Parameters for Reaches . . . . . . . . . . . . . 12

Hydrology . . . . . . . . . . . . . . . . . 12

Bed Material Gradation $\ldots \ldots \ldots \ldots \ldots \ldots \ldots \ldots \ldots \ldots$

Critical Shear Stress $\ldots \ldots \ldots \ldots \ldots \ldots \ldots \ldots \ldots \ldots . . \ldots \ldots$

Sediment Transport . . . . . . . . . . . . . . . . 21

Bed Material Sediment Yield . . . . . . . . . . . . . 22

Sediment Budget . . . . . . . . . . . . . . . . 23

Impacts of Diversion at Ruxton Creek $\ldots \ldots \ldots \ldots \ldots \ldots 24$

3-Total Sediment Yield . . . . . . . . . . . . . . . 26

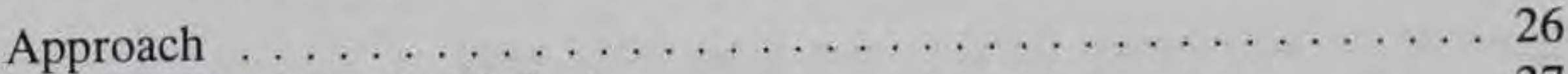

Los Angeles District Method . . . . . . . . . . . . . . 27

Pacific Southwest Inter-agency Committee Method (PSIAC) . . . . . 31

Reservoir Survey Comparisons . . . . . . . . . . . . . . . 33

Total Sediment Yield Results . . . . . . . . . . . . . . . 34

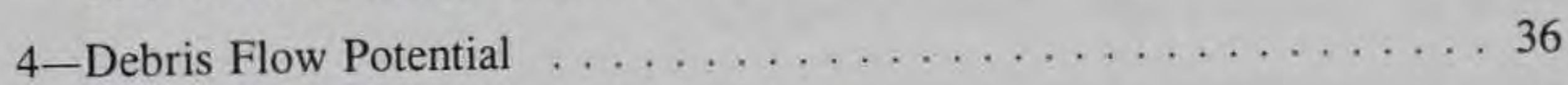

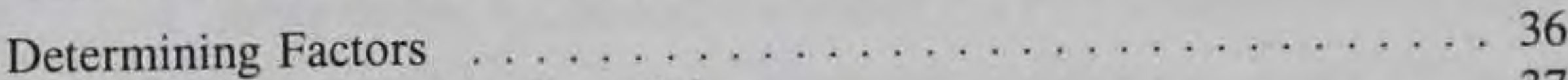

Analysis of Debris Flow Potential $\ldots \ldots \ldots \ldots \ldots \ldots \ldots . \ldots \ldots$

5-Summary and Recommendations ................. 39

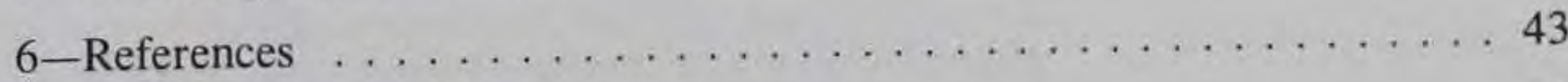

Appendix A: Sediment Yield Tables $\ldots \ldots \ldots \ldots \ldots \ldots \ldots$ A1 


\section{List of Figures}

Figure 1. Location and vicinity map $\ldots \ldots \ldots \ldots \ldots \ldots \ldots$

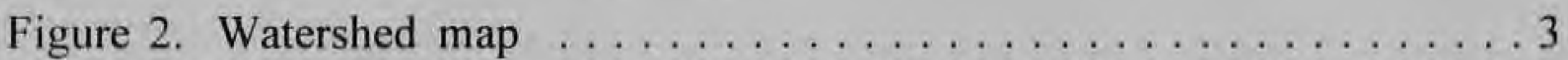

Figure 3. Boundary shear stress, 1 percent chance peak

exceedance discharge $\ldots \ldots \ldots \ldots \ldots \ldots \ldots \ldots \ldots$

Figure 4. Boundary shear stress, 50 percent chance peak

exceedance discharge $\ldots \ldots \ldots \ldots \ldots \ldots \ldots \ldots$

Figure 5. Channel discharge, 1 percent chance peak exceedance discharge $\ldots \ldots \ldots \ldots \ldots \ldots \ldots \ldots$

Figure 6. Channel discharge, 50 percent chance peak exceedance discharge $\ldots \ldots \ldots \ldots \ldots \ldots \ldots \ldots$

Figure 7. Channel velocity, 1 percent chance peak exceedance discharge $\ldots \ldots \ldots \ldots \ldots \ldots \ldots \ldots \ldots$

Figure 8. Channel velocity, 50 percent chance peak exceedance discharge $\ldots \ldots \ldots \ldots \ldots \ldots \ldots \ldots \ldots$

Figure 9. Froude number, 1 percent chance peak exceedance discharge $\ldots \ldots \ldots \ldots \ldots \ldots \ldots \ldots \ldots \ldots$

Figure 10. Froude number, 50 percent chance peak exceedance discharge $\ldots \ldots \ldots \ldots \ldots \ldots \ldots \ldots \ldots \ldots$

Figure 11. Water-surface profiles for supply reach and Reach $2 \ldots \ldots 13$

Figure 12. Water-surface profiles for Reach $3 \ldots \ldots \ldots \ldots \ldots \ldots$

Figure 13. Water-surface profiles for Reaches 4 and $5 \ldots \ldots \ldots 15$

Figure 14. One percent chance exceedance hydrograph for Fountain Creek $\ldots \ldots \ldots \ldots \ldots \ldots \ldots \ldots \ldots$

Figure 15. Flow duration curve, water years $1958-1992 \ldots \ldots \ldots \ldots$

Figure 16. Bed gradations - surface and subsurface $\ldots \ldots \ldots \ldots$

Figure 17. Boundary shear stress for $100 \mathrm{cfs} \ldots \ldots \ldots \ldots \ldots$

Figure 18 . Boundary shear stress for $340 \mathrm{cfs} \ldots \ldots \ldots \ldots \ldots \ldots$

Figure 19. Fire factor curve for watersheds 0.1 to 2.0 square miles . . . 29

Figure 20. Fire factor curves for watersheds from 3.0 to

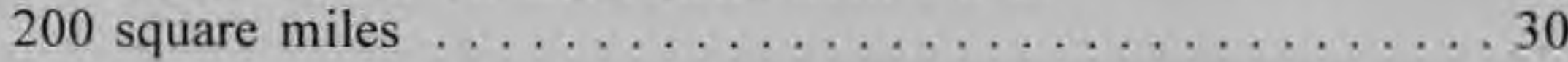




\section{Preface}

The sediment impact assessment for Manitou Springs, CO, was conducted at the U.S. Army Engineer Waterways Experiment Station (WES) at the request of the U.S. Army Engineer Disirict, Albuquerque (SWA). It was prepared in support of the Manitou Springs Reconnaissance Report.

This investigation was conducted during the period September to November 1994 in the Hydraulics Laboratory of WES, under the direction of Messrs. Frank A. Herrmann, Jr., Director of the Hydraulics Laboratory; Richard A. Sager, Assistant Director of the Hydraulics Laboratory; Dr. Larry L. Daggett, Chief of the Waterways Division (WD), Hydraulics Laboratory; and Mr. Michael J. Trawle, Chief of the Math Modeling Branch (MMB), WD. The project engineer was Dr. Ronald R. Copeland, MMB. Authors of the report were Dr. Copeland and Ms. Lisa C. Hubbard, MMB.

During the course of this study, close working contact was maintained with Mr. Bruce Beach, SWA, who served as coordinating engineer, providing required data, technical assistance, and review

At the time of publication of this report, Director of WES was Dr. Robert W. Whalin. Commander was COL Bruce K. Howard, EN.

The contents of this report are not to be used for advertising, publication, or promotional purposes. Citation of trade names does not constitute an official endorsement or approval of the use of such commercial products. 


\section{Conversion Factors, Non-SI to SI Units of Measurement}

Non-SI units of measurement used in this report can be converted to SI units as follows:

\begin{tabular}{||l|l|l||}
\hline Multiply & By & To Obtain \\
\hline \hline acre-feet & $4,046.873$ & cubic meters \\
\hline cubic feet & 0.02831685 & cubic meters \\
\hline cubic yards & 0.7645549 & cubic meters \\
\hline inches & 2.54 & centimeters \\
\hline Fahrenheit degrees & $5 / 9$ & Celsius degrees or kelvins' \\
\hline feet & 0.3048 & meters \\
\hline miles (U.S. statute) & 1.609347 & kilometers \\
\hline pounds (force) per square foot & 47.88 & Pascals \\
\hline pounds (mass) per cubic foot & 16.01846 & kilograms per cubic meter \\
\hline square miles & 2.589998 & square kilometers \\
\hline \hline $\begin{array}{l}\text { To obtain Celsius (C) temperature readings from Fahrenheit (F) readings, use the following } \\
\text { formula: C = (5/9)(F - 32). To obtain Kelvin (K) readings, use: K }=(5 / 9)(F-32)+273.15 .\end{array}$ \\
\hline \hline
\end{tabular}




\section{Introduction}

\section{Location}

The city of Manitou Springs is located in central Colorado, just west of Colorado Springs, in a narrow, steep-walled mountain canyon that contains Fountain Creek. The town was developed as a resort around the natural mineral springs in the area, and remains a popular tourist destination. Over the years, residential and commercial development has encroached into the natural streambed of Fountain Creek. The creek is further constricted by several bridges and culvert crossings and in some locations by major roads paralleling the creek. These alterations to the natural creek channel have increased the risk of flooding and channel instability in Manitou Springs. The study area extends from the downstream, or eastern, city limit of Manitou Springs, near Columbia Road, upstream to a location about $2,000 \mathrm{ft}^{1}$ upstream from Park Avenue. A location and vicinity map is shown in Figure 1.

\section{Watershed Characteristics}

The drainage area of Fountain Creek at the eastern city limit of Manitou Springs is about 103 square miles. The headwaters are located in the mountains of the Rampart Range. The drainage basin includes Pikes Peak, which rises to an elevation of $14,110 \mathrm{ft}^{2}{ }^{2}$ The elevation in Fountain Creek at the downstream study limit is about $6,060 \mathrm{ft}$. The watershed is typically mountain terrain with steep rough slopes. Fountain Creek is a perennial stream, fed from glacial snowpacks and springs. A watershed map is shown in Figure 2.

Vegetation varies throughout the drainage basin. In areas above the timberline, vegetation is sparse. In the timber and woodland areas aspen, oak brush, spruce, juniper, and native grasses are found.

1 A table of factors for converting non-SI units of measurement to SI units is found on page vi.

2 All elevations (el) cited herein are in feet referred to the National Geodetic Vertical Datum (NGVD). 


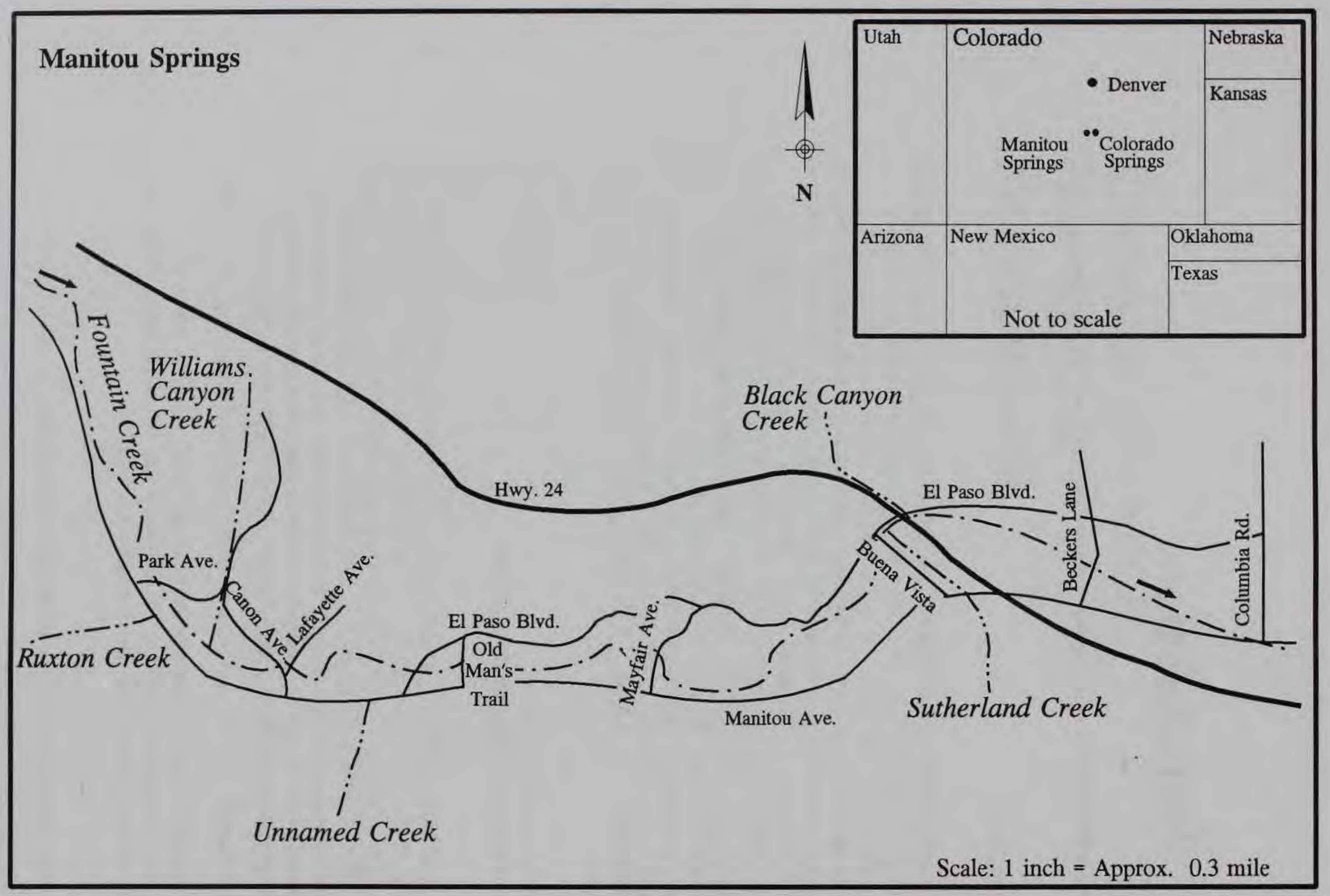

Figure 1. Location and vicinity map 


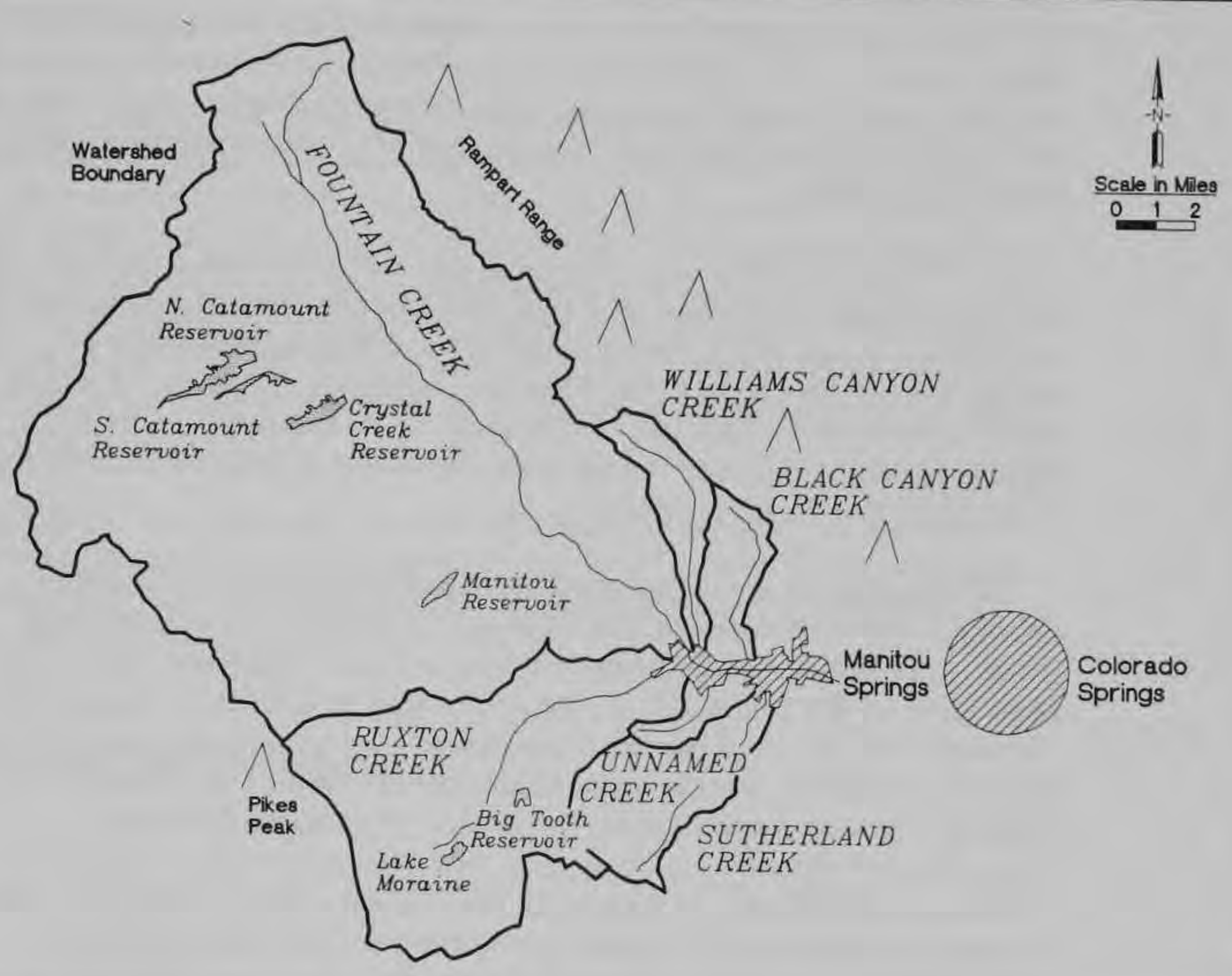

Figure 2. Watershed map

Four tributaries join Fountain Creek in the study reach, as listed in the following tabulation:

\begin{tabular}{||l|l||}
\hline Creek & $\begin{array}{l}\text { Drainage Area } \\
\text { square miles }\end{array}$ \\
\hline \hline Fountain Creek upstream from Manitou Springs & 70 \\
\hline Ruxton Creek & 17.8 \\
\hline Williams Canyon Creek & 2.7 \\
\hline Sutherland Creek & 5.2 \\
\hline Black Canyon Creek & 2.6 \\
\hline Fountain Creek downstream from Manitou Springs & 103 \\
\hline
\end{tabular}

Ruxton Creek flows in a northeasterly direction to join Fountain Creek at Manitou Springs. Like that of Fountain Creek, the watershed is typically steep mountain terrain with steep rough slopes. Elevations range between 
$14,110 \mathrm{ft}$ at Pikes Peak to $6,330 \mathrm{ft}$ at the confluence with Fountain Creek. Two water supply reservoirs are in the watershed: Lake Moraine and Big Tooth Reservoir. The last half mile of the channel is constricted by bridges and culverts as it traverses residential and commercial developments. The last $400 \mathrm{ft}$ of Ruxton Creek upstream from its confluence with Fountain Creek are completely covered.

The Williams Canyon Creek watershed lies north of Manitou Springs. Williams Canyon Creek flows in a southerly direction from its headwaters in the Rampart Range to join Fountain Creek just below the confluence of Ruxton Creek. Elevations in the watershed range from $9,400 \mathrm{ft}$ to $6,320 \mathrm{ft}$. The original creek channel has been replaced by underground conduits through the city of Manitou Springs from the mouth of Williams Canyon for about $1,000 \mathrm{ft}$ to Fountain Creek.

Sutherland Creek flows in a northeasterly direction and joins Fountain Creek just upstream from the U.S. Highway 24 crossing. The Sutherland Creek watershed lies south and east of Ruxton Creek watershed. Elevations range from $10,800 \mathrm{ft}$ to $6,220 \mathrm{ft}$. The confluence of Sutherland Creek with Fountain Creek has been relocated due to highway construction. In its present location the creek is severely constricted upstream from its confluence with Fountain Creek by a small culvert that passes under Manitou Avenue.

Black Canyon Creek lies directly east of Williams Canyon Creek and flows in a southerly direction to join Fountain Creek just downstream from the U.S. Highway 24 crossing. Elevations in the watershed range from 8,200 to $6,210 \mathrm{ft}$.

\section{Valley and Streambed Characteristics}

Fountain Creek's valley through Manitou Springs upstream from U.S. Highway 24 has an average width of about $400 \mathrm{ft}$, and the channel varies in width between 12 and $50 \mathrm{ft}$. Through town the channel is severely constricted by bridges and building foundations. Several channel stabilizers with 1- or 2$\mathrm{ft}$ drops have been constructed across the streambed. Downstream from U.S. Highway 24 , the valley width averages about $600 \mathrm{ft}$, and the channel width varies between 50 and $100 \mathrm{ft}$.

The composition of the streambed varies. In some locations the bed is covered with cobbles and boulders, in other locations sand and gravel. In some locations there are abundant quantities of rubble on the bed. Although not observed during the field investigation, an earlier report (U.S. Army Engineer District (USAED), Albuquerque, 1974) stated that bedrock outcrops are also present. 


\section{Climate and Precipitation}

In the mountainous areas, precipitation varies widely over relatively short distances, and much of the total precipitation at these higher elevations is in the form of snow. In the Fountain Creek watershed, snowmelt seldom produces floods except when augmented by rainfall. Average annual precipitation varies between 24 in. at Lake Moraine and 13 in. at Colorado Springs. Most of the flood-producing storms occur between May and August. The physical features of the watershed are all conducive to a rapid concentration of runoff resulting in flash floods characterized by high peak flows, moderate volumes, and short durations.

Temperatures vary widely because of altitude differences. Mean annual maximum temperatures vary between 47 and $63^{\circ} \mathrm{F}$. Mean annual minimum temperatures vary between 24 and $35^{\circ} \mathrm{F}$. Recorded extreme temperatures vary between -37 and $100{ }^{\circ} \mathrm{F}$.

\section{Purpose of the Study}

The purpose of the sediment impact assessment is to identify the magnitude of sediment problems that might be associated with proposed flood-control projects for Manitou Springs and to recommend appropriate sedimentation studies for the next level of planning study. For a reconnaissance level planning study, this may be accomplished by evaluating channel stability using a sediment budget approach. Bed material sediment yields for specific channel reaches, and for project and existing conditions are compared. When there are significant differences in calculated sediment yields between one reach and another or between existing and project conditions, a sedimentation problem has been identified. The sediment impact assessment also provides an inventory of available sediment data and recommends data collection programs if appropriate.

The sediment impact assessment also includes estimates of sediment yield for purposes of sizing reservoirs and/or debris basins. These estimates are approximate in the reconnaissance level study due to the lack of detailed watershed data. Data collection requirements for more detailed sediment yield studies are identified in the sediment impact assessment.

At the time of this study no specific flood-control plans had been formulated, so comparison of existing and project plans was limited. The sediment impacts of a plan to divert all flows greater than $500 \mathrm{cfs}$ just downstream from Park Avenue and then return the diverted flows downstream from U.S. Highway 24 was evaluated. 


\section{Approach}

Sediment transport and sediment yields for the sediment budget approach were determined using techniques based on uniform flow assumptions. This technique is recognized to be untenable for final design, especially in streams such as Fountain Creek with widely variable characteristics. However, it is deemed adequate to identify the magnitude of sediment problems and to evaluate relative impacts for a variety of proposed flood-control project plans. Hydraulic parameters for the sediment budget were determined from reachaveraged values taken from the HEC-2 backwater model (U.S. Army Engineer Hydrologic Engineering Center (USAEHEC) 1990). The SAM hydraulic design package (Thomas et al., in preparation) was used to calculate sediment transport and the bed material sediment yield.

There is no generally accepted method to calculate total sediment yield. In order to obtain a range of probable sediment yields for a 1 percent chance exceedance hydrograph and for average annual conditions, sediment yields were calculated using methods developed for watersheds with somewhat similar conditions. This approach provides a range of volume requirements for construction of reservoirs or debris basins. Further study would be required if the sediment storage option is pursued in the next level of study. 


\section{Channel Stability}

\section{Channel Geometry}

The Albuquerque District developed a HEC-2 (USAEHEC 1990) backwater model using cross sections taken from topographic mapping with a scale of $1 \mathrm{in}$. $=400 \mathrm{ft}$ with 5 - $\mathrm{ft}$ contour intervals, modified somewhat using field surveys. The model extended from the eastern city limits of Manitou Springs near Columbia Road for about $14,200 \mathrm{ft}$ upstream to the western city limits. This model was used in the sediment impact assessment study to obtain reachaveraged values for important hydraulic variables.

Plots of calculated average boundary shear stress, channel discharge, channel velocity, and Froude number for the 1 percent and 50 percent chance peak exceedance discharges are shown in Figures 3-10. Distances in plots are measured in feet upstream from Columbia Road. These critical hydraulic parameters vary significantly through the study reach. This is due partially to poor channel definition at some of the cross sections, but is due primarily to numerous constrictions by culverts, bridges, and channel encroachment by structures. This variability suggests a wide range in streambed characteristics and channel stability conditions in the study reach, and makes it difficult to apply simple reach-averaged analysis techniques to Fountain Creek. An adequate sediment analysis would require a HEC-6 numerical simulation that accounts for nonuniform water and sediment discharges (USAEHEC 1993).

The reach-averaged hydraulic variables of width, depth, slope, and velocity must be considered approximate, because the topographic mapping scale used to define the cross sections is not detailed enough to obtain sufficiently accurate channel definition. In addition, the backwater model did not include the effect of channel stabilizers, many of which cause a drop in the channel invert of between 1 and $2 \mathrm{ft}$. This effect may be significant at lower discharges. Future sedimentation studies should be conducted using new topographic mapping at a scale of $1 \mathrm{in}$. $=100 \mathrm{ft}$, which will provide much better geometric definition. However, cross sections developed from the new topographic mapping will still require refinements based on field surveys. 


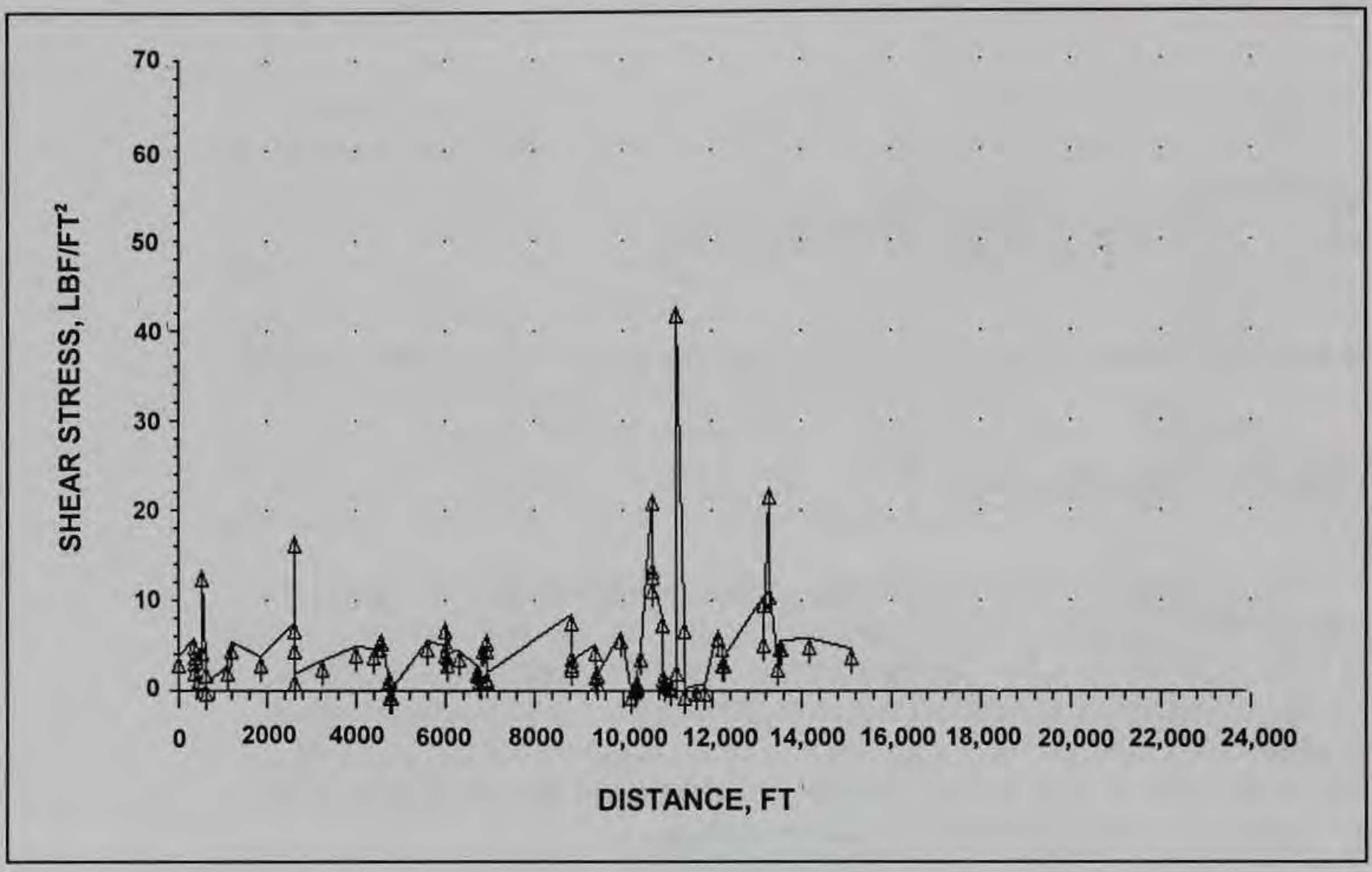

Figure 3. Boundary shear stress, 1 percent chance peak exceedence discharge

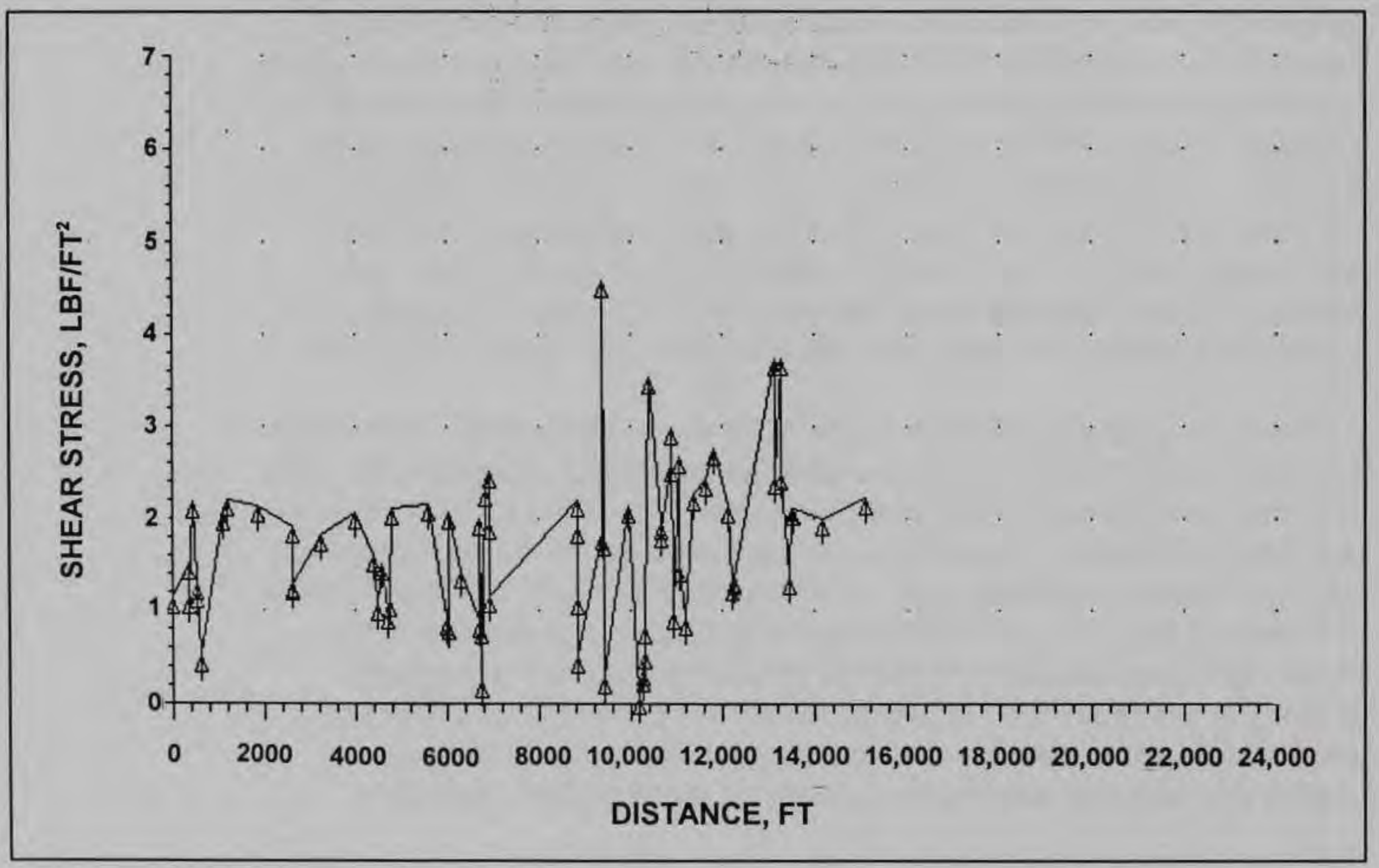

Figure 4. Boundary shear stress, 50 percent chance peak exceedence discharge 


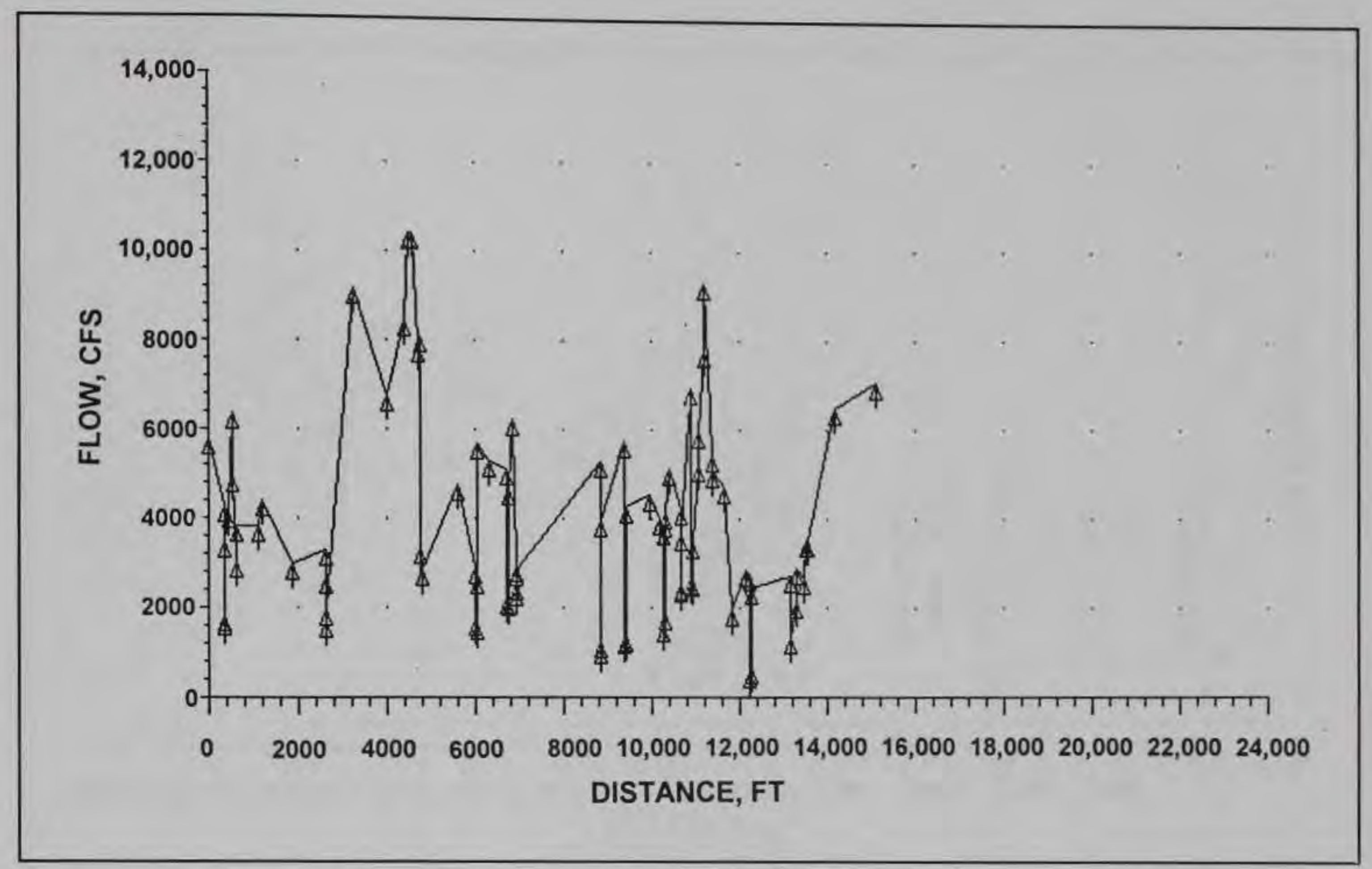

Figure 5. Channel discharge, 1 percent chance peak exceedence discharge

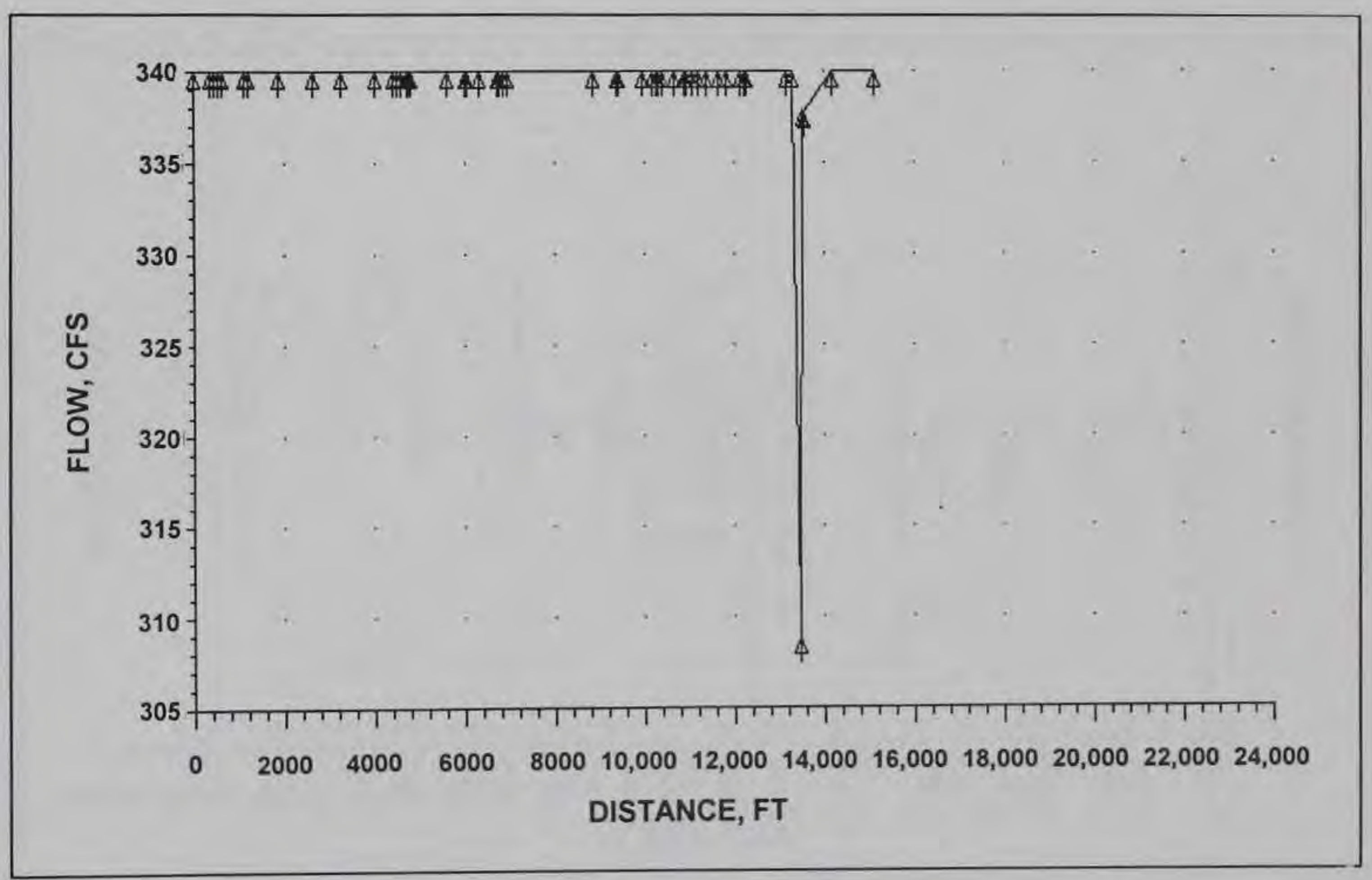

Figure 6. Channel discharge, 50 percent chance peak exceedence discharge 


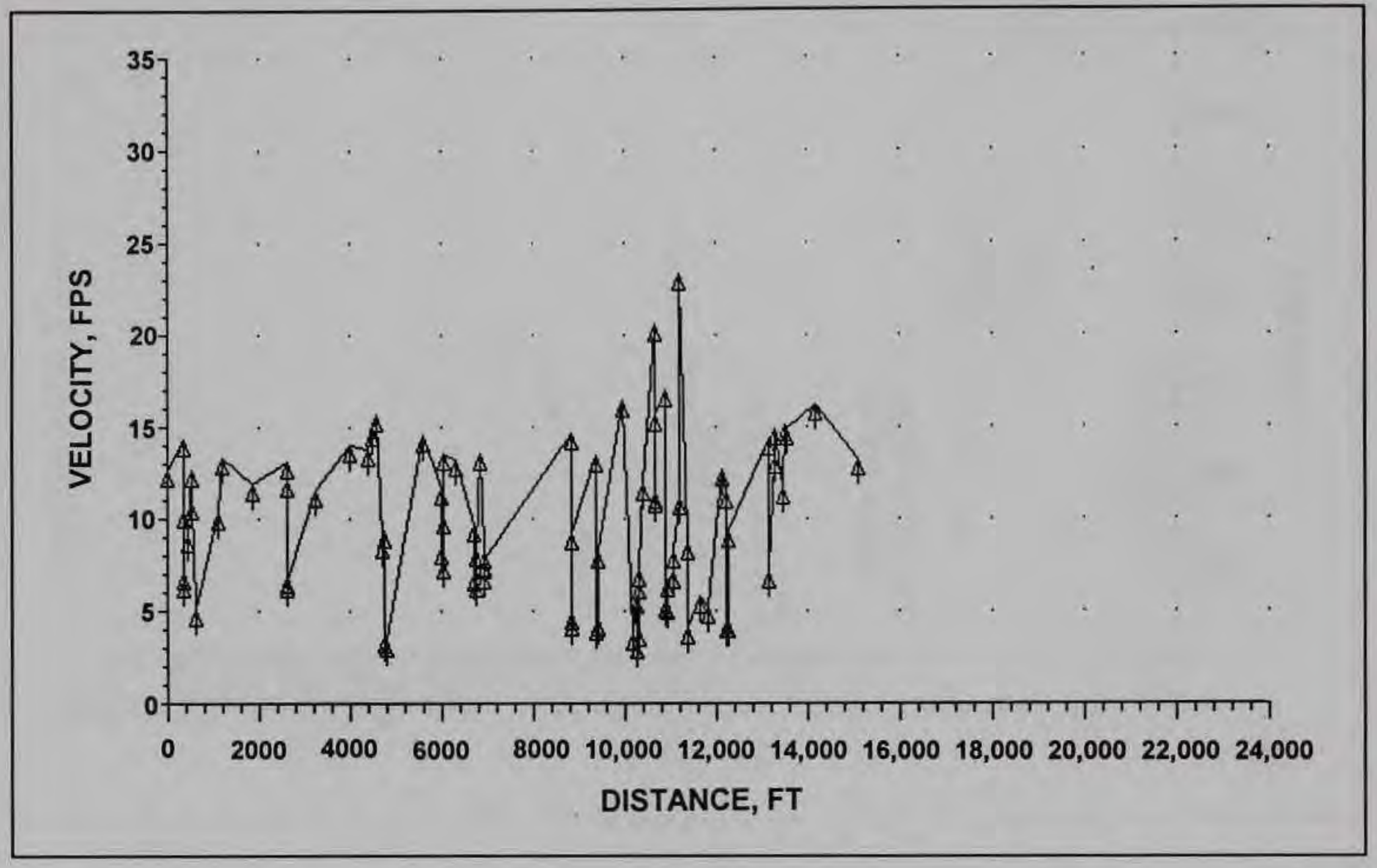

Figure 7. Channel velocity, 1 percent chance peak exceedence discharge

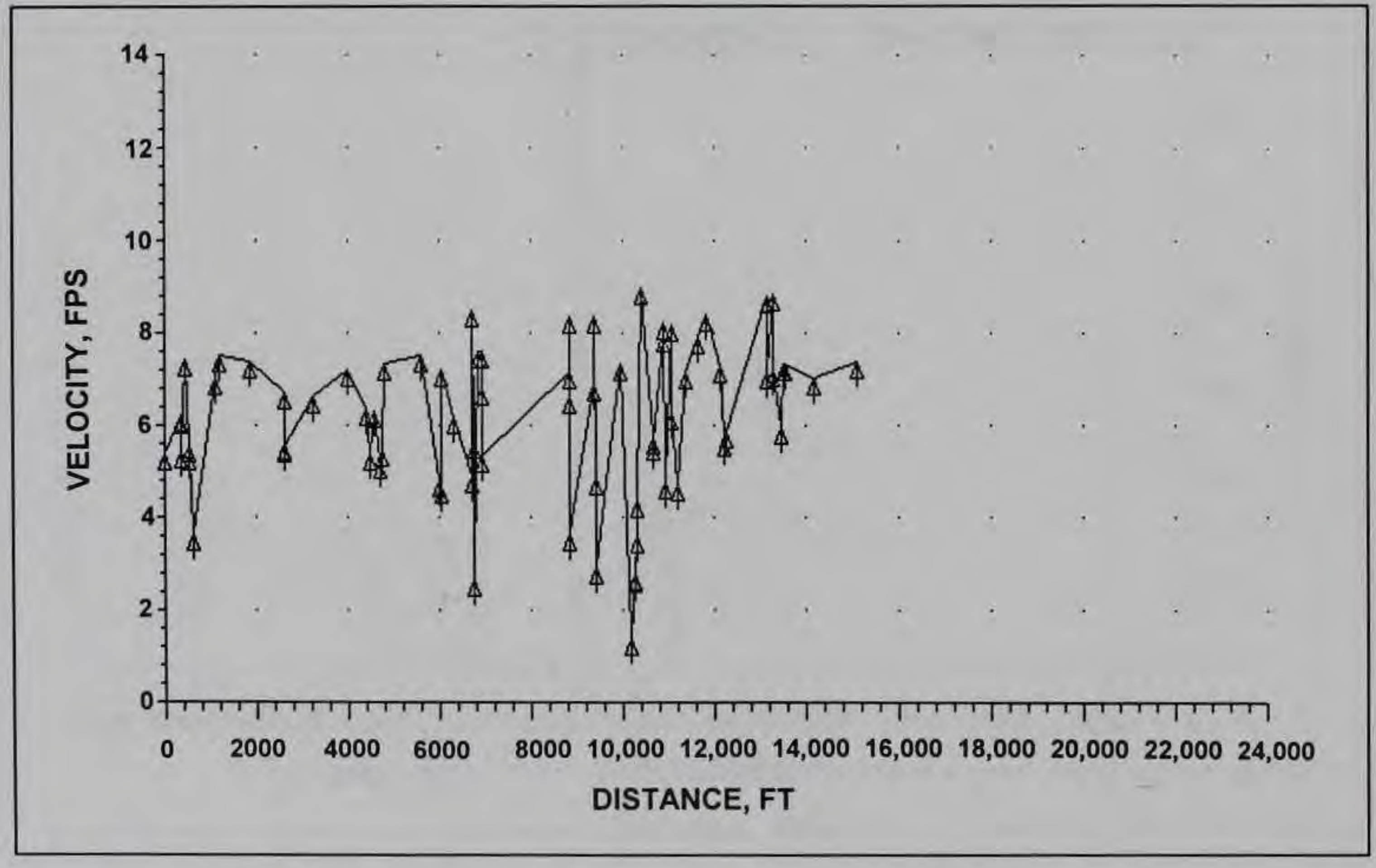

Figure 8. Channel velocity, 50 percent chance peak exceedence discharge 


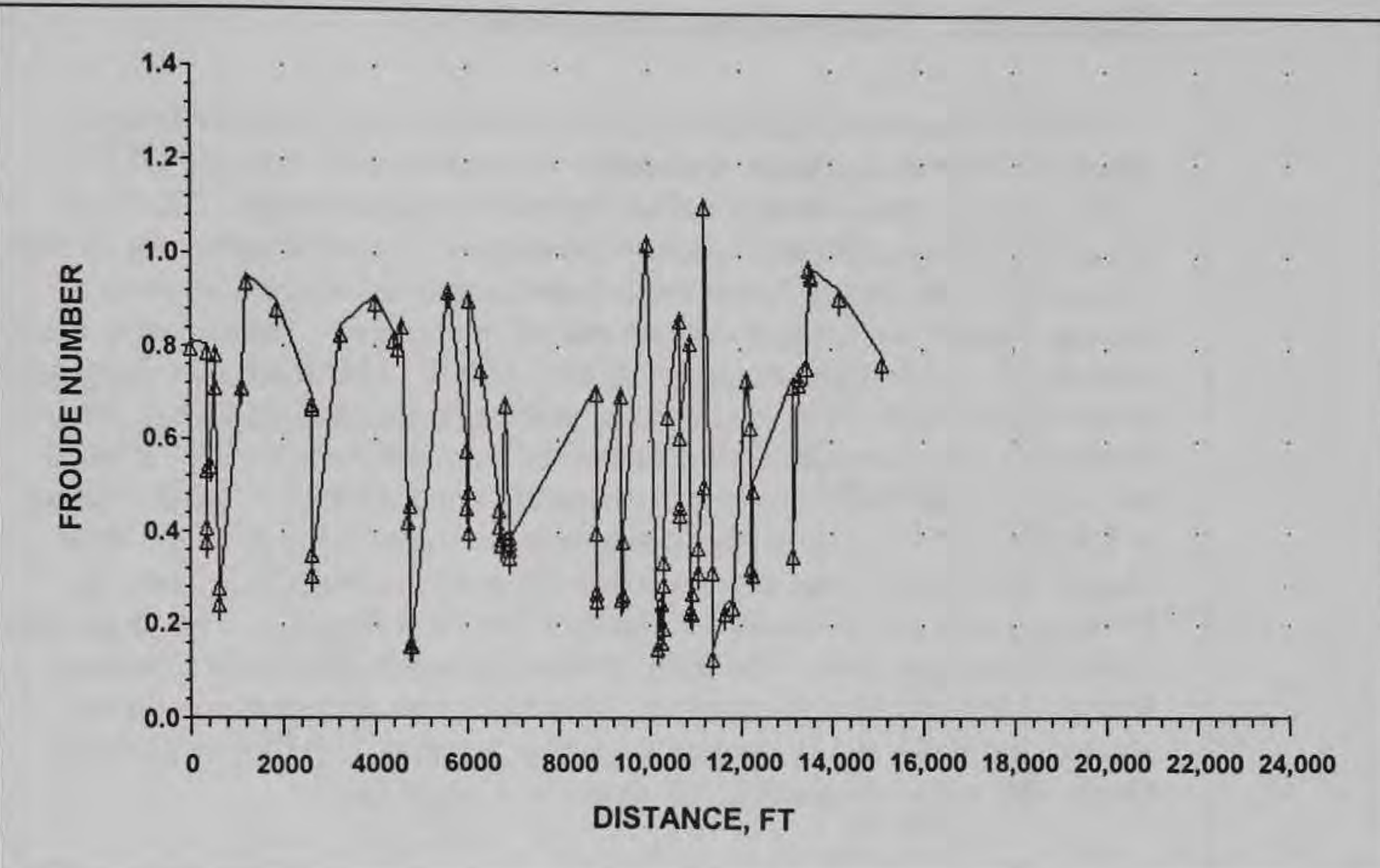

Figure 9. Froude number, 1 percent chance peak exceedence discharge

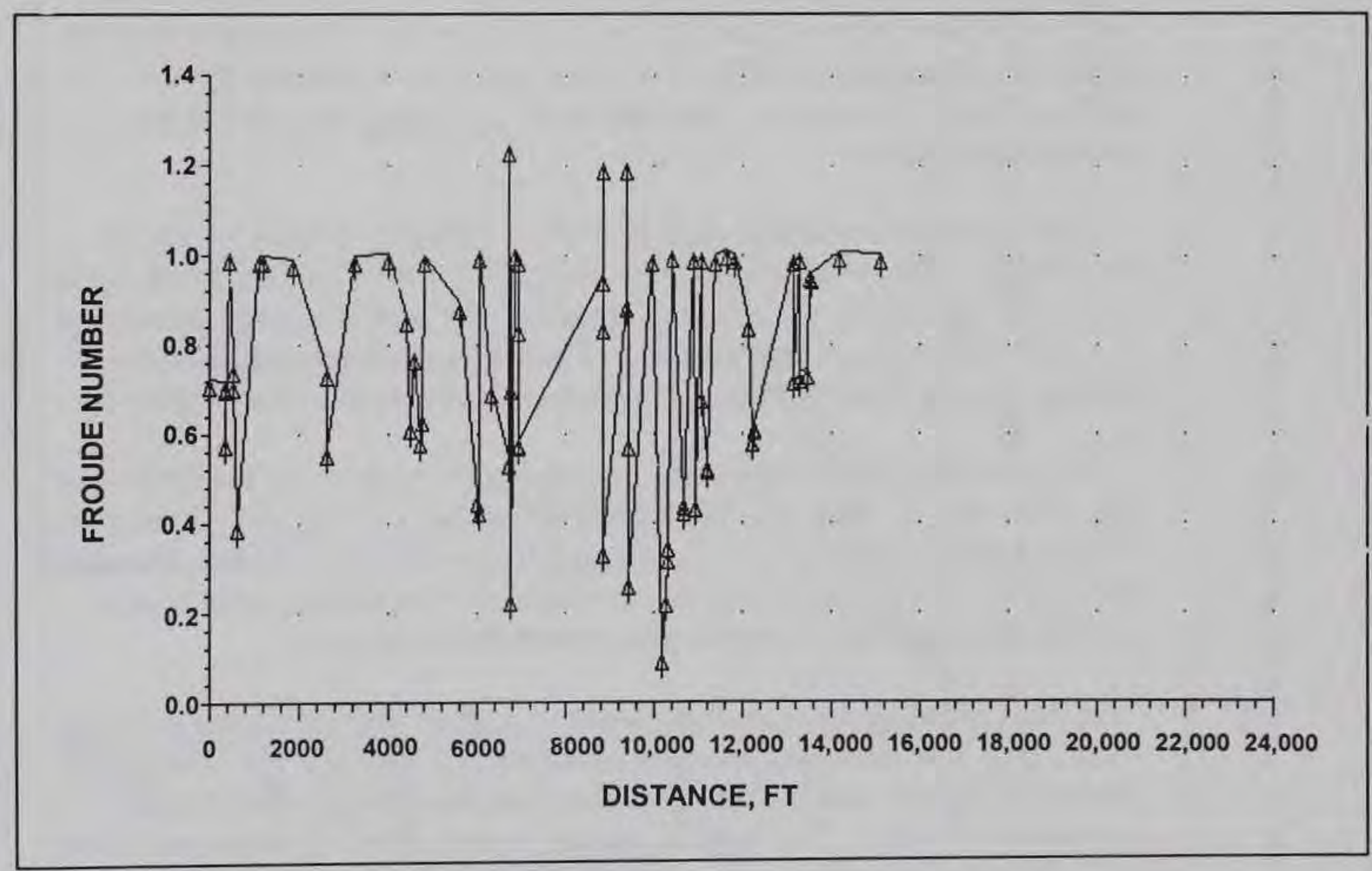

Figure 10. Froude number, 50 percent chance peak exceedence discharge 


\section{Hydraulic Parameters for Reaches}

The study reach was divided into five reaches for the sediment budget analysis. Average hydraulic parameters were determined from the HEC-2 output for each reach using the SAM hydraulic design package. The SAM program weights calculated hydraulic parameters by reach length. An attempt was made in the designation of reach boundaries to avoid cross sections through bridges and immediately upstream from bridges. The upstream reach extended from Park Avenue upstream for $1,900 \mathrm{ft}$. This reach was designated as the supply reach. The next downstream reach, Reach 2 , extended from the confluence of Ruxton Creek downstream to Lafayette Avenue, and included the most commercially developed portion of Fountain Creek. Reach 3 began at Old Mans Trail and extended downstream to Buena Vista Avenue. The channel in this reach was also constricted at many locations. Downstream between Buena Vista Avenue and Beckers Lane was Reach 4. This reach was relatively unconstricted. The most downstream reach was Reach 5 between Beckers Lane and Manitou Avenue. This reach was also relatively unconstricted, but had a milder average slope than Reach 4. Profiles of Fountain Creek with reach designations are shown in Figures 11-13.

\section{Hydrology}

The peak discharges and hydrographs used in this sediment impact assessment were taken from a hydrology report prepared by Albuquerque District (USAED, Albuquerque, 1994). Peak discharges were obtained from a regional frequency analysis. Reported peak discharges are listed in the tabulation on page 16 .

The Albuquerque District used the HEC-1 Flood Hydrograph Package (USAEHEC 1981) to obtain flood hydrographs for the Fountain Creek watershed. The model was calibrated to reproduce the peak discharge determined from the regional frequency analysis. The 1 percent chance exceedance hydrographs for three locations on Fountain Creek are shown in Figure 14.

Rainfall for various percent chance exceedance frequencies for the 6-hour and 1-hour storms were obtained from the National Oceanic and Atmospheric Administration (NOAA) Atlas 2, Volume III, for Colorado (Miller, Frederick, and Tracey 1973). Depth-area curves obtained from NOAA Atlas 2 were used to determine the average depth for each drainage basin.

A flow duration curve was developed to analyze average annual sediment yield. The flow duration curve was based on data from the U.S. Geological Survey (USGS) Fountain Creek near Colorado Springs gage, which has operated since 1958 . This gage is located about 0.5 mile downstream of the U.S. Highway 24 bridge, and monitors a drainage area of 103 square miles. The flow duration curve developed from 33 years of mean daily flow records was modified to account for peak flows. The USGS publishes all peak flows 


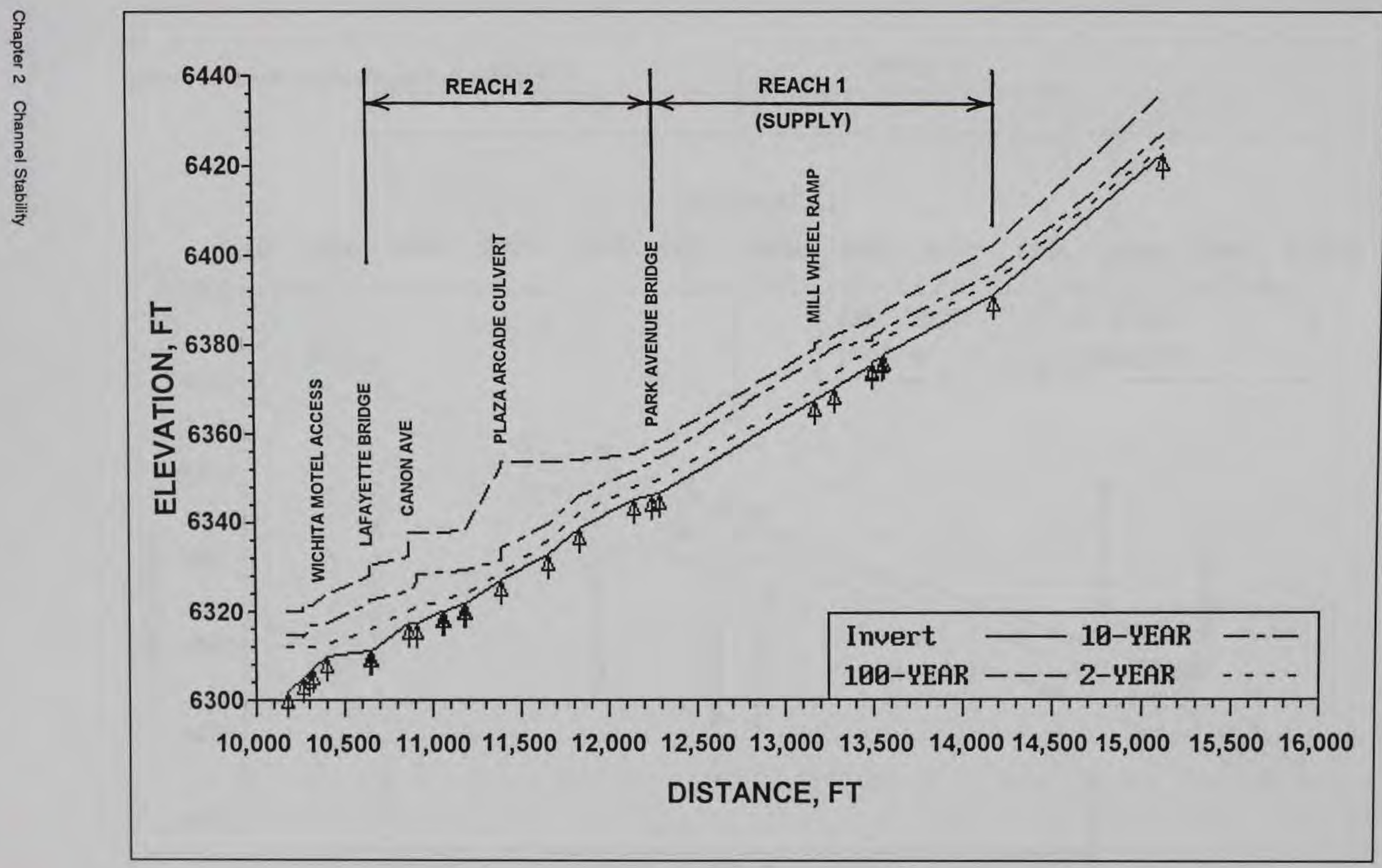

Figure 11. Water-surface profiles for supply reach and Reach 2 


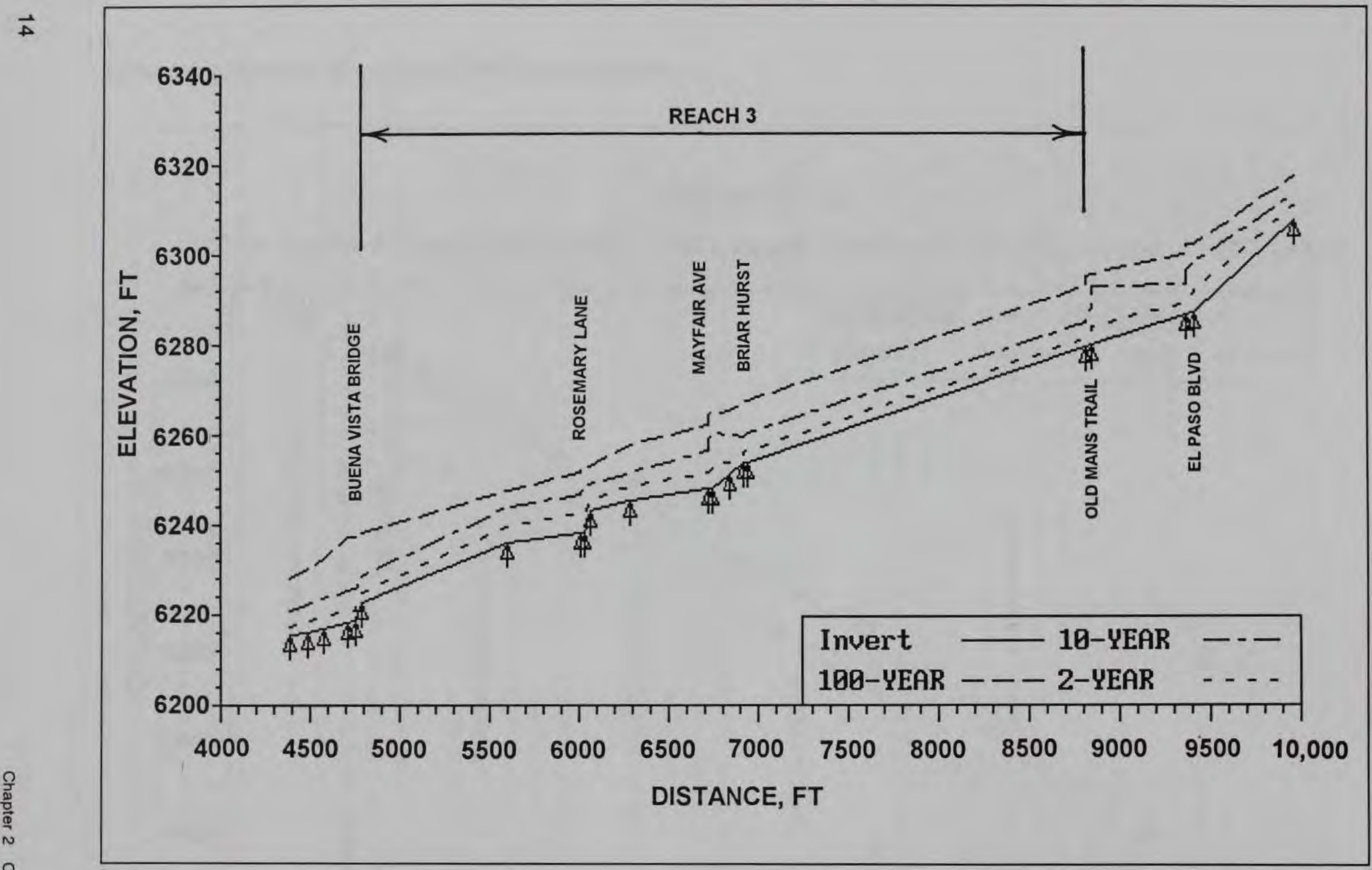

Figure 12. Water-surface profiles for Reach 3 


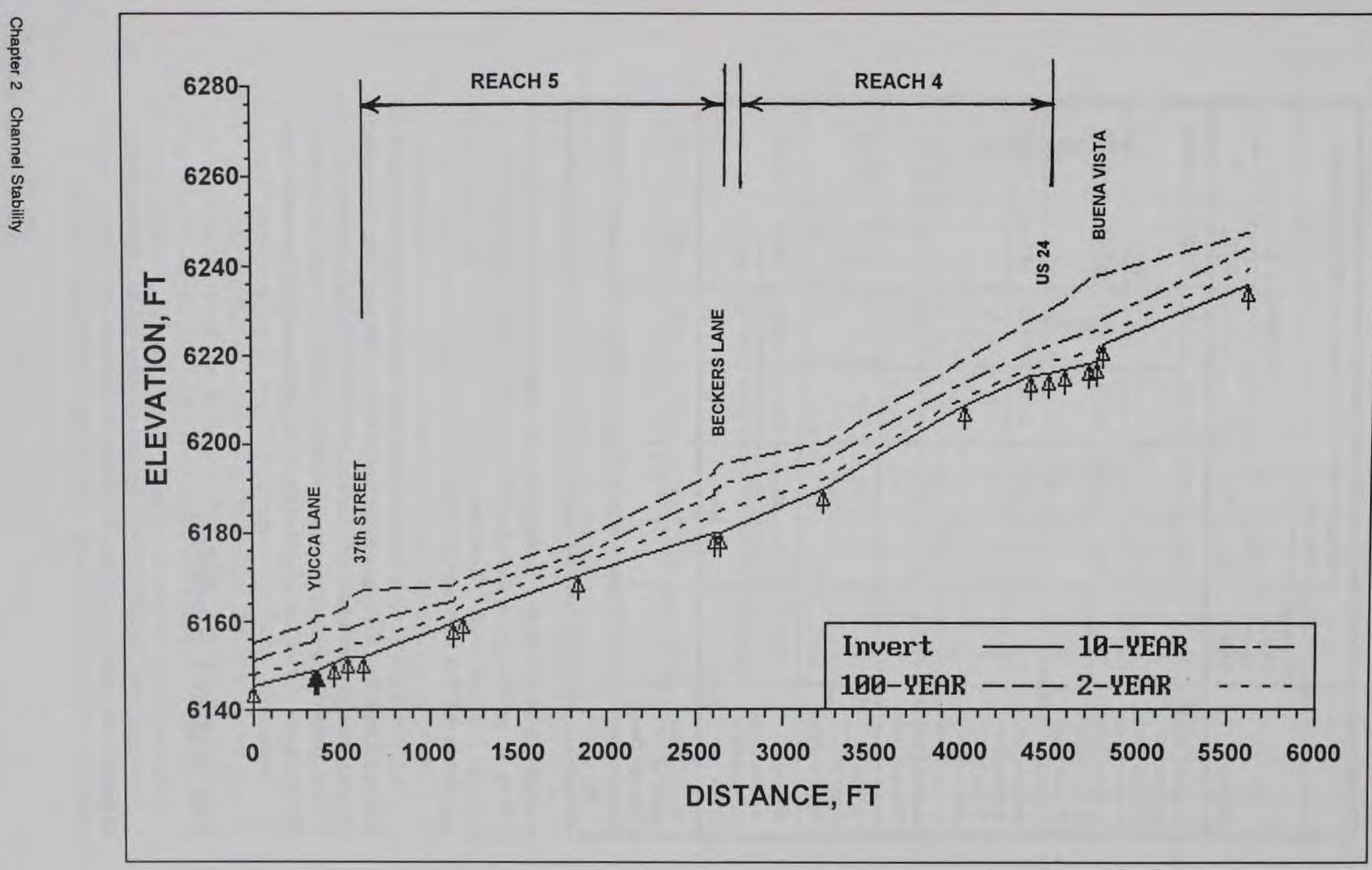

Figure 13. Water-surface profiles for Reaches 4 and 5 


\begin{tabular}{|c|c|c|c|c|c|c|c|}
\hline \multirow[b]{3}{*}{ Location } & \multirow{3}{*}{$\begin{array}{l}\text { Drainage } \\
\text { Area } \\
\text { square } \\
\text { miles }\end{array}$} & \multicolumn{6}{|c|}{$\begin{array}{l}\text { Percent Chance That Discharge, cfs, Will Be Exceeded in } \\
\text { Any Year }\end{array}$} \\
\hline & & \multicolumn{6}{|c|}{ Percent Chance } \\
\hline & & 50 & 10 & 4 & 2 & 1 & 0.2 \\
\hline $\begin{array}{l}\text { Fountain Creek } \\
\text { upstream of } \\
\text { Ruxton Creek }\end{array}$ & 70 & 340 & 1,400 & 3,400 & 5,300 & 7,300 & 13,400 \\
\hline $\begin{array}{l}\text { Fountain Creek } \\
\text { downstream of } \\
\text { Ruxton Creek }\end{array}$ & 88 & 340 & 1,700 & 4,000 & 6,500 & 9,300 & 16,400 \\
\hline $\begin{array}{l}\text { Fountain Creek } \\
\text { downstream of } \\
\text { Sutherland } \\
\text { Creek }\end{array}$ & 103 & 340 & 1,960 & 4,600 & 7,000 & 10,400 & 17,600 \\
\hline $\begin{array}{l}\text { Ruxton Creek at } \\
\text { Fountain Creek }\end{array}$ & 17.8 & -1 & 370 & 940 & 1,700 & 2,800 & 5,600 \\
\hline $\begin{array}{l}\text { Sutherland } \\
\text { Creek at } \\
\text { Fountain Creek }\end{array}$ & 5.2 & -1 & 110 & 370 & 690 & 1,090 & 2,100 \\
\hline $\begin{array}{l}\text { Williams } \\
\text { Canyon Creek } \\
\text { at Fountain } \\
\text { Creek }\end{array}$ & 2.7 & -1 & 61 & 250 & 420 & 660 & 1,160 \\
\hline $\begin{array}{l}\text { Black Canyon } \\
\text { Creek at } \\
\text { Fountain Creek }\end{array}$ & 2.6 & -1 & 60 & 220 & 410 & 650 & 1,250 \\
\hline
\end{tabular}

over $250 \mathrm{cfs}$ for this gage. Hydrographs for these peak flows were assumed to have the same shape as the 1 percent chance exceedance hydrograph computed for Fountain Creek. Exceedance times for these peak hydrographs were included in the flow duration curve shown in Figure 15.

Albuquerque District (USAED, Albuquerque, 1994) determined that the Fountain Creek near Colorado Springs gage has experienced peak flows that are unrealistically low when compared to other stream gauges in the region. This suggests that the average annual sediment yields calculated with a flow duration curve developed using data from this gage may produce values that are also too low.

\section{Bed Material Gradation}

Fountain Creek through Manitou Springs has variable bed characteristics. In general, the bed is composed of cobbles and boulders overlying a finer substrate that contains sediment sizes from medium sand through boulders. A 


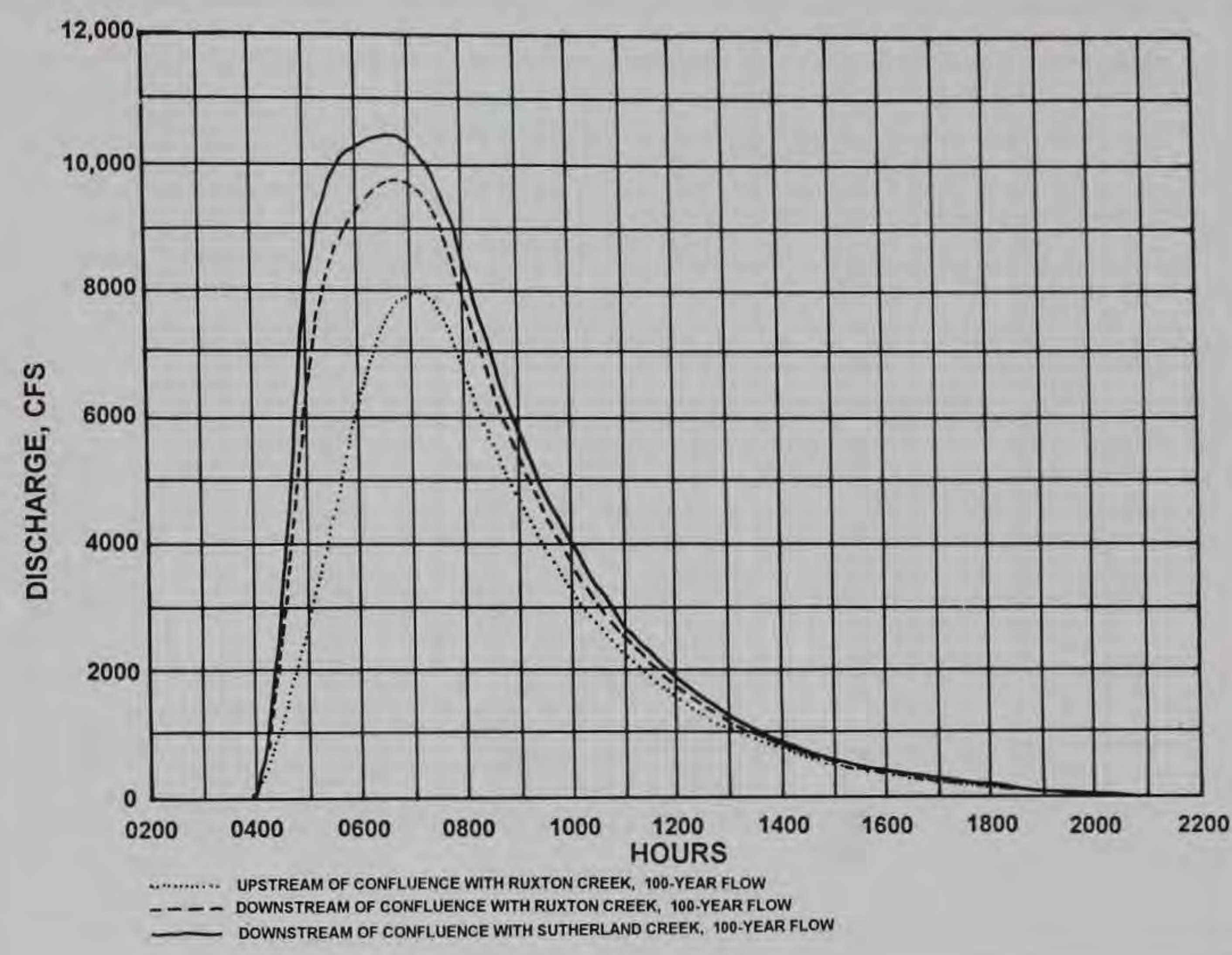

Figure 14. One percent chance exceedance hydrograph for Fountain Creek

variety of construction activities within the channel have provided effective control points. These include concrete inverts, log stabilizers, and dumped rubble. These local hydraulic controls typically reduce velocities upstream, resulting in a sand and gravel bed. In other locations the bed is effectively armored with larger gravels, cobbles, and boulders.

During a field reconnaissance in September 1994, samples of the coarse surface layer and of the finer sand and gravel bed material were obtained. The coarse surface layer was determined in Fountain Creek about $300 \mathrm{ft}$ downstream from Park Avenue. The surface layer gradation was determined using the Wolman (1954) method. One hundred grains were randomly collected from the bed surface and measured. Fifty feet upstream from Mayfair Avenue a bed sample was taken from a point bar just above the water surface level about midway along the bar. The sample was collected with a shovel about 4 in. deep into the bar. The bed gradations are plotted in Figure 16. For purposes of this study, the surface layer gradation was used to determine critical shear stress, and the point bar gradation was assumed to represent a subsurface gradation and was used to calculate sediment transport once the critical shear stress was exceeded. 


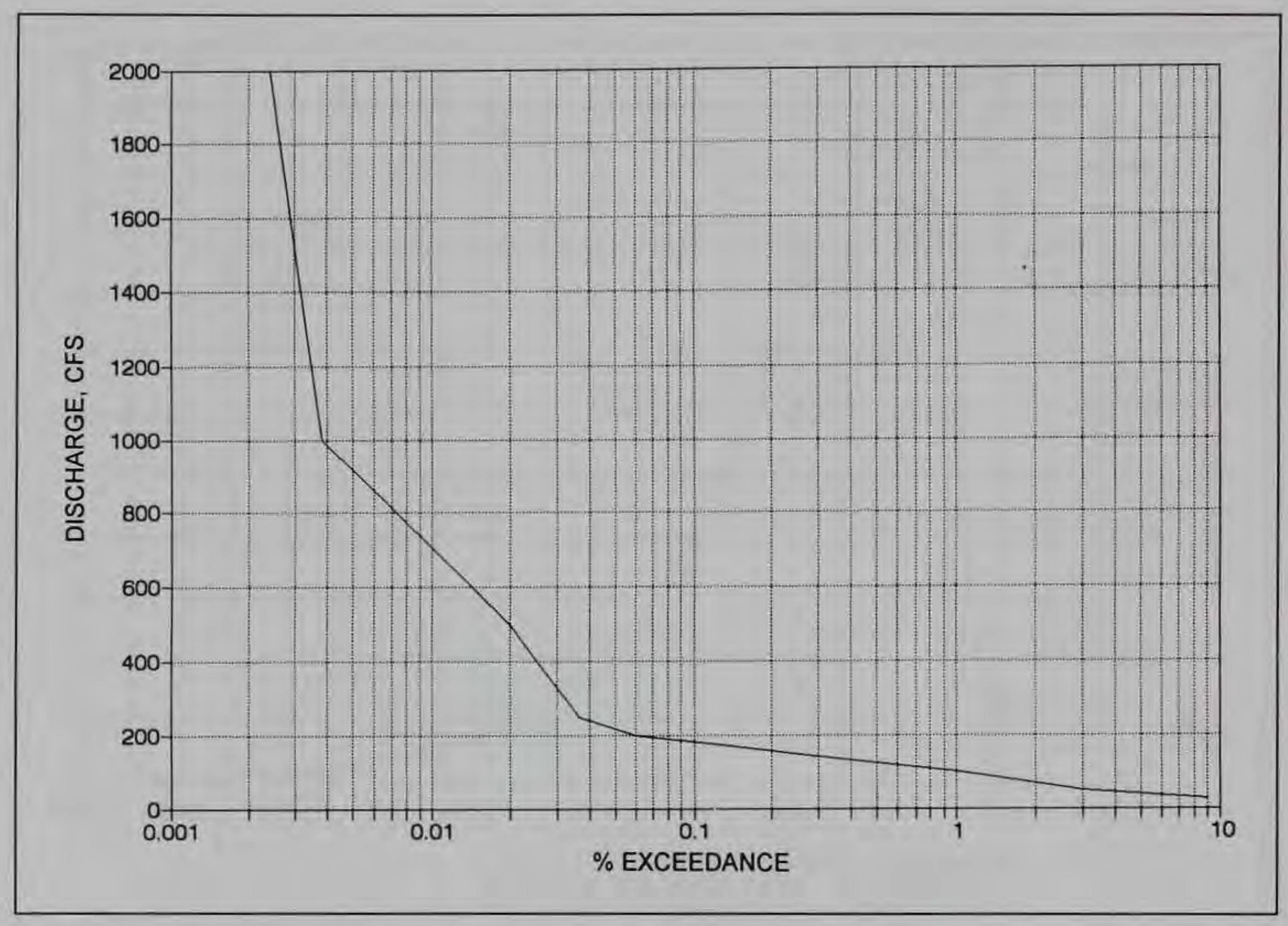

Figure 15. Flow duration curve, water years 1958-1992

\section{Critical Shear Stress}

The coarse surface layer on the bed of much of Fountain Creek serves to prevent the underlying sand and gravel from becoming entrained into the flow and thus protects the bed from erosion. However, at high flows this armor layer may be destroyed, exposing the underlying material to entrainment and transport. When this happens, sediment transport potential is greatly increased. To calculate a sediment transport rating curve for a range of discharges, it is necessary to estimate the discharge at which the armor layer is no longer effective. Gessler (1971) determined from flume studies that the movement of coarse-grained material from the surface layer was a probabilistic process and that a portion of the coarse surface layer would remain effective until the applied bed shear stress was about twice the critical shear stress. The critical shear stress can be calculated from Equation 1:

$$
\tau_{c}=0.047\left(\gamma_{s}-\gamma\right) d_{50}
$$




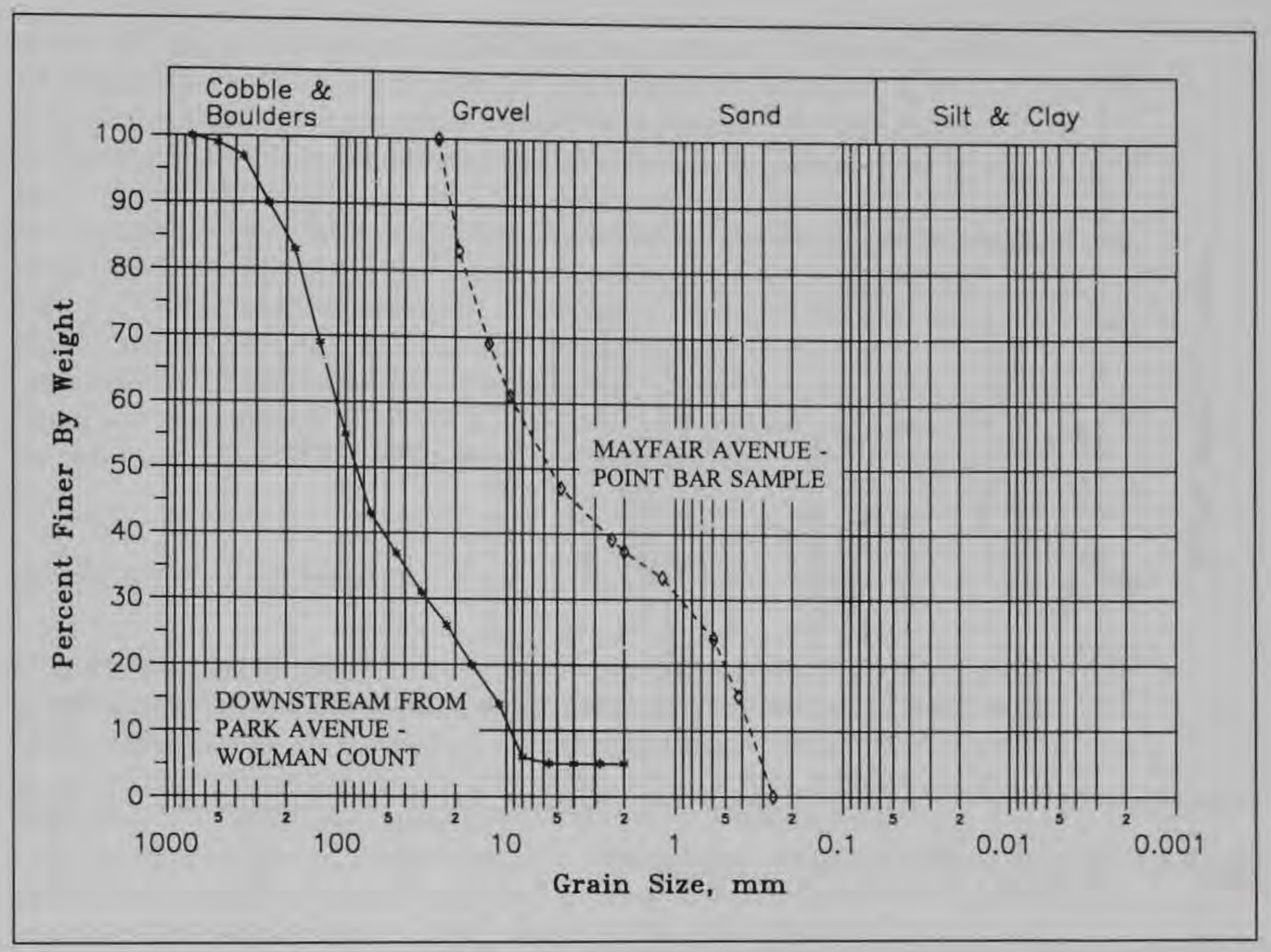

Figure 16. Bed gradations-surface and subsurface

where

$$
\begin{aligned}
& \tau_{\mathrm{c}}=\text { critical shear stress } \\
& \gamma_{\mathrm{s}}=\text { specific weight of sediment } \\
& \gamma=\text { specific weight of water } \\
& \mathrm{d}_{50}=\text { median grain size }
\end{aligned}
$$

The surface layer sample from Fountain Creek downstream from Park Avenue indicated an armor layer median grain size of $80 \mathrm{~mm}(0.2625 \mathrm{ft})$. Assuming a specific weight of sediment of $165 \mathrm{lbf} / \mathrm{cu} \mathrm{ft}$ yields a critical shear stress of $1.27 \mathrm{lbf} / \mathrm{sq} \mathrm{ft}$.

Average boundary shear stress in the channel for each cross section in the HEC- 2 backwater model was calculated for a range of discharges and compared to the critical shear stress and twice the critical shear stress. These comparisons for 100 and $340 \mathrm{cfs}$ ( 50 percent chance peak exceedance frequency) are shown in Figures 17 and 18 . At $100 \mathrm{cfs}$, boundary shear stress is below the critical shear stress for the majority of the cross sections and below 


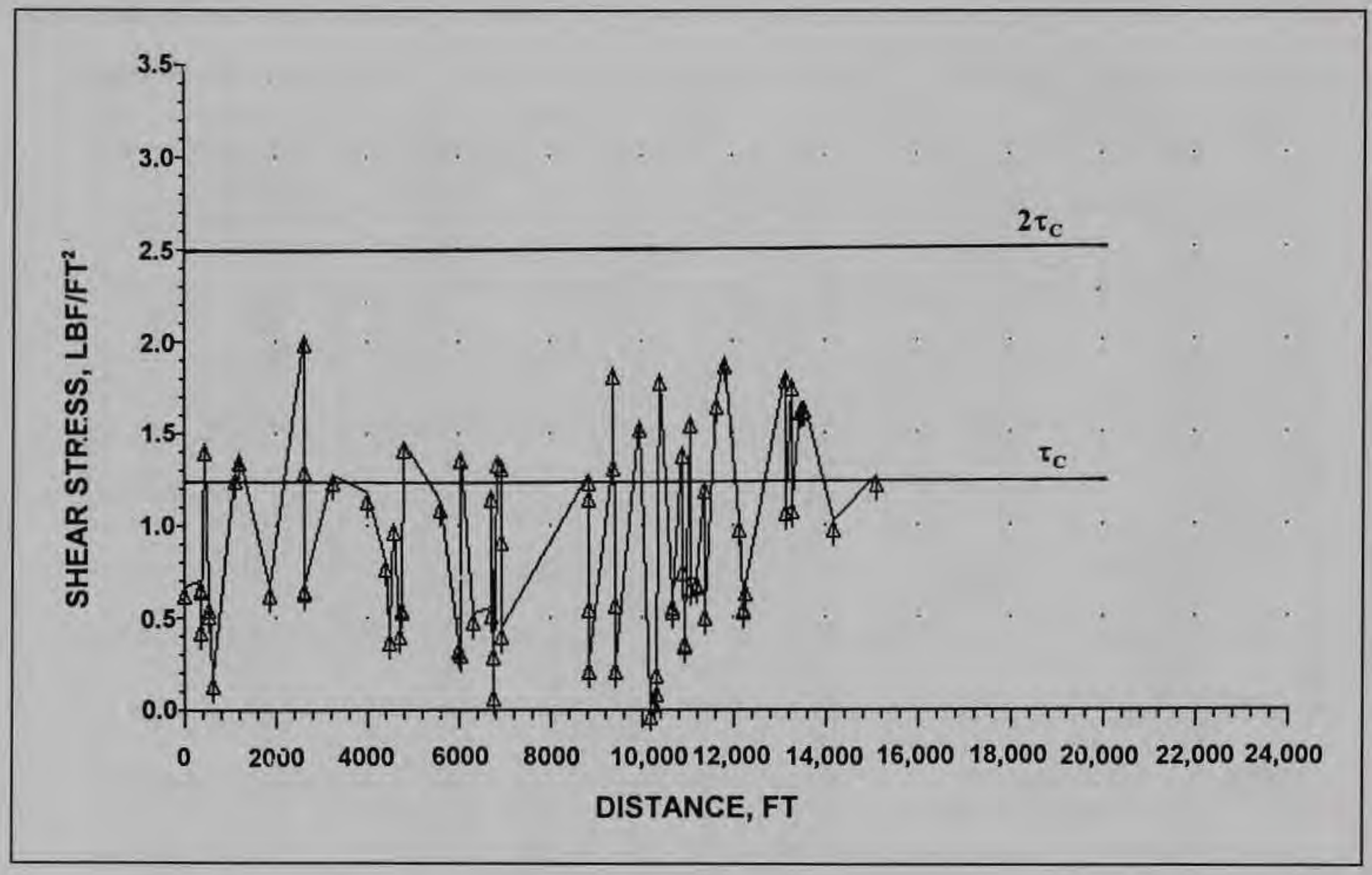

Figure 17. Boundary shear stress for $100 \mathrm{cfs}$

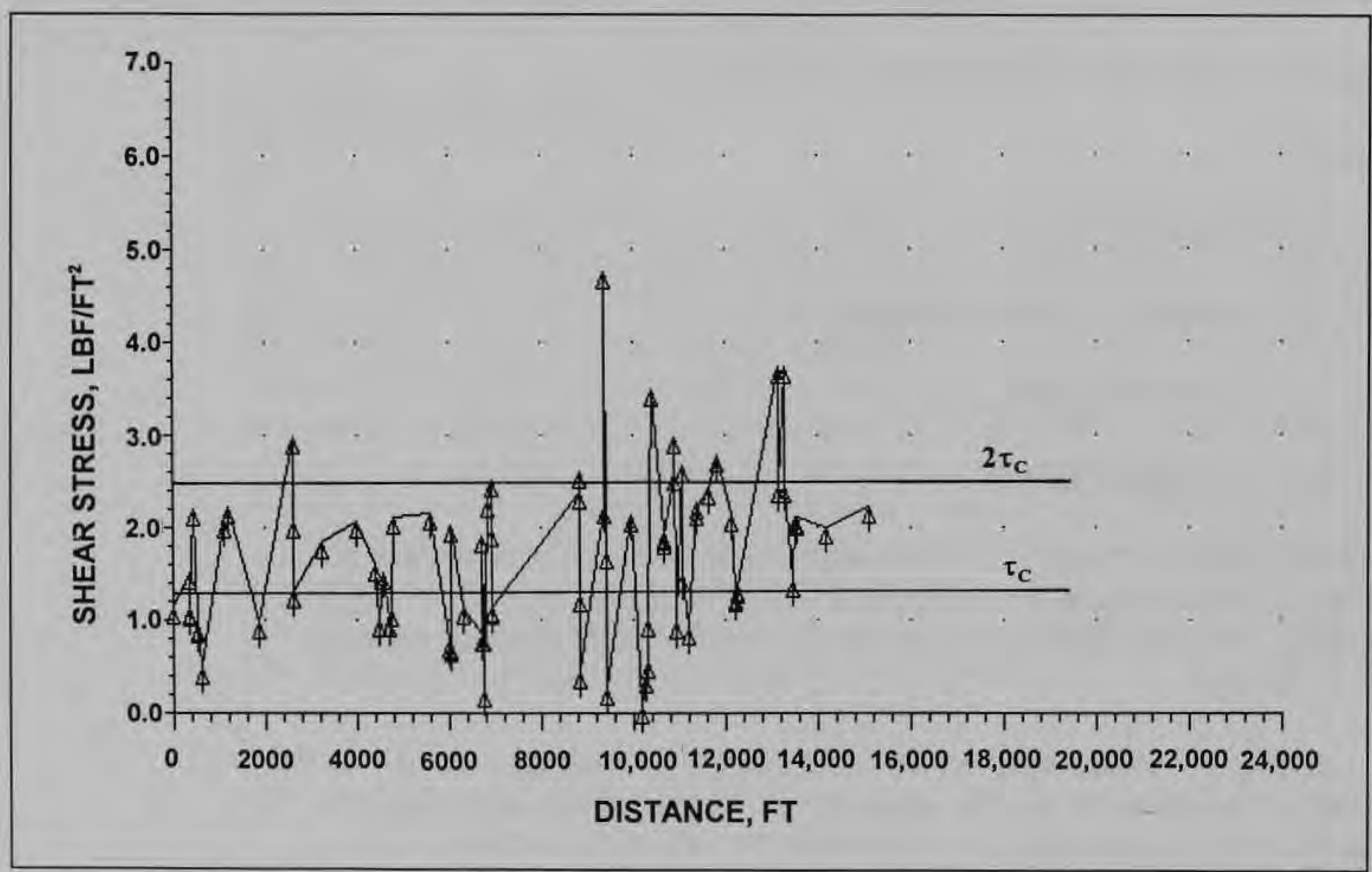

Figure 18. Boundary shear stress for $340 \mathrm{cfs}$ 
twice the critical shear stress for all of the cross sections. Therefore, at this discharge, the armor layer was assumed to be intact and the armor layer gradation was used in the sediment transport calculations. At $340 \mathrm{cfs}$ the boundary shear stress in the channel was greater than the critical shear stress for a majority of the cross sections, and above twice the critical shear stress for some of the cross sections. Therefore, at this and greater discharges the armor layer was assumed to be ineffective and the finer bed gradation was used to calculate sediment transport. This analysis assumes that the bed gradation taken from the point bar upstream from Mayfair Avenue is representative of the typical subsurface gradation in Fountain Creek throughout the study reach. This is a significant assumption that should be verified in a more detailed sediment sampling program.

\section{Sediment Transport}

Sediment transport in Fountain Creek can be divided into two categories: wash load and bed material load. Wash load is the finer sediment load that is supplied by the watershed and does not depend on the hydraulic characteristics in the channel. Wash load does not exchange with the bed, although some wash load grain sizes may appear in the bed due to entrapment behind localized obstructions or deposits due to receding flows. Einstein (1950) suggested that the lower 10 percent of a bed gradation curve should be discounted to account for wash load in the bed. Bed material load is the load that actively exchanges with the bed and can be calculated given the bed material gradation and the hydraulic characteristics of the channel. Sediment transport equations predict only the bed material load. Bed material load is the sediment load that affects channel change and is the important load when considering channel stability.

There is no generally acceptable sediment transport equation for streams characteristic of Fountain Creek. Sediment transport equations are notorious for predicting widely variable results. This is especially true for streams with coarse surface layers. The surface layer will provide a variable degree of protection to the underlying material depending on the hydraulic conditions. Upstream supply to any given reach is also critical to the development of the surface layer and the sediment transport rate. In Fountain Creek, sediment transport rates will also be highly variable due to the variability in cross-section shape and to the flashy nature of the flood hydrographs. The approach taken here was to calculate sediment yield using several transport functions and then choose three that produced a reasonable range of results, recognizing that quantitative results cannot be accurately obtained using a uniform flow approach.

Much better quantitative results can be obtained using the HEC-6 numerical sedimentation model (USAEHEC 1993). This model will account for variable armoring and for the variation in channel cross-sectional areas. Careful adjustment of the model will produce a more reliable estimate of bed material transport through Manitou Springs. 


\section{Bed Material Sediment Yield}

Bed material sediment yield was calculated using the flow durationsediment discharge-rating curve method described in Engineer Manual (EM) 1110-2-4000 (Headquarters, U.S. Army Corps of Engineers, 1989). The SAM hydraulic design package was used to make the calculations. Flow duration curves were developed for the mean annual flow, the 50 percent chance exceedance hydrograph, and the 1 percent chance exceedance hydrograph. Sediment discharge rating curves, required for this method, were developed for each reach using three sediment transport functions.

The three sediment transport functions used in this study were chosen from eleven different sediment transport functions available in the SAM hydraulic design package. The eleven equations chosen for initial consideration have been used successfully on other sand and gravel bed streams. These equations are divided into two categories: those developed to calculate the bed-load component of the bed material load, and those developed to calculate the total bed material load. In order to compare the sediment transport equations, sediment yield in the supply reach was calculated for the 1 percent exceedance hydrograph, the 50 percent exceedance hydrograph, and for average annual conditions using the flow duration curve. Results are presented in Table Al. There was a wide range in calculated yields depending on which equation was used. Since there are no available measured sediment concentration data to circumstantiate the sediment transport equations, the choice of equations was based on judgment. Bed-load equations were excluded because suspended load may be a significant contributor to the sediment load at high flows. The Laursen-Copeland and Englund-Hansen equations were excluded because calculated concentrations at low flows were unreasonably high. A reasonable range of calculated sediment yields were obtained using the Yang, AckersWhite, and Toffaleti-Schoklitsch equations.

The following sediment yields were calculated from the study reach using the three sediment transport functions:

\begin{tabular}{|c|c|c|c|}
\hline \multirow[b]{2}{*}{ Sediment Transport Equation } & \multicolumn{3}{|c|}{ Bed Material Load, cu yd } \\
\hline & $\begin{array}{l}\text { Average } \\
\text { Annual }\end{array}$ & $\begin{array}{l}50 \text { Percent } \\
\text { Chance } \\
\text { Exceedance } \\
\text { Hydrograph }\end{array}$ & $\begin{array}{l}1 \text { Percent } \\
\text { Chance } \\
\text { Exceedance } \\
\text { Hydrograph }\end{array}$ \\
\hline Ackers-White & 90 & 310 & 4,500 \\
\hline Yang & 150 & 660 & 10,200 \\
\hline Toffaleti-Schoklitsch & 380 & 920 & 7,100 \\
\hline
\end{tabular}

The calculations are based on reach-averaged hydraulic parameters. Bed material gradations were based on the surface or subsurface sample as discussed in the section, "Bed Material Gradation." 


\section{Sediment Budget}

The calculated sediment yields for each reach were compared to the calculated sediment yield for the reach immediately upstream to determine if there was a trend for aggradation or degradation. This treatment means that the most upstream reach is taken to be the supply reach and is assumed to be in equilibrium. Different sediment transport equations produced different calculated sediment yield quantities and therefore different amounts of degradation or aggradation. However, each equation predicted relatively consistent values in terms of the percent of the upstream sediment load that could be transported through the reach. The sediment budget does not account for the change in sediment transport capacity that would occur with significant deposition or scour, and therefore the calculated aggradation or degradation would be overpredicted. Calculated percentages averaged from the three sediment transport equations are listed in the following tabulation:

\begin{tabular}{||l|l|l|l||}
\hline \multirow{2}{*}{ Reach } & \multicolumn{3}{|c||}{ Percent of Sediment from Upstream Reach Passing this Reach } \\
\cline { 2 - 4 } & Average Annual & $\begin{array}{l}\text { 50 percent Chance } \\
\text { Exceedance } \\
\text { Hydrograph }\end{array}$ & $\begin{array}{l}\text { 1 percent Chance } \\
\text { Exceedance } \\
\text { Hydrograph }\end{array}$ \\
\hline \hline 2 & 48 & 62 & 64 \\
\hline 3 & 103 & 98 & 120 \\
\hline 4 & 186 & 170 & 272 \\
\hline 5 & 68 & 81 & 50 \\
\hline
\end{tabular}

The sediment budget indicates that in Reach 2, downstream from Ruxton Creek to Lafayette Avenue, between 52 and 36 percent of the incoming bed material sediment load would be expected to deposit in the channel depending on the hydrograph. This deposition is attributed to channel constrictions and the resulting backwater in this reach, which passes through the most commercially developed portion of Fountain Creek. Reach 3, the next reach downstream, between Old Mans Trail and Buena Vista Avenue, can be expected to experience degradation during the 1 percent chance exceedance hydrograph, but should be stable in terms of aggradation and degradation during the 50 percent chance exceedance hydrograph and on an average annual basis. Reach 4, between Buena Vista Avenue and Beckers Lane, is steeper than Reach 3 upstream, and has fewer constrictions. As a result, sediment transport potential is significantly greater in this reach, and the sediment budget analysis indicates that the channel should degrade, especially during the 1 percent chance exceedance hydrograph. The most downstream reach, between Beckers Lane and Manitou Avenue, also lacks constrictions, but has a milder slope than the upstream reach so that aggradation is predicted. Calculated sediment yields are presented in Table A2. 
The sediment budget analysis indicates significant variability in sediment transport capacity in Fountain Creek through Manitou Springs. This suggests channel stability problems even with the existing channel conditions. To quantify the magnitude of the channel stability problem, better definition of the channel bed material and channel cross section will be required. A more detailed sediment study should include a thorough channel bed inventory, identifying both surface and subsurface gradations and bedrock outcrops, along Fountain Creek. It is expected that the bed material gradations will vary longitudinally through the study reach. Special care should be taken to identify bed conditions at locations where degradation is predicted. Locations and reliability of channel bed stabilizers should also be determined.

\section{Impacts of Diversion at Ruxton Creek}

One flood-control alternative that is being considered is the diversion of flood flows in excess of channel capacity downstream from Park Avenue. The diverted flows would then be returned to Fountain Creek downstream of U.S. Highway 24. Details for this alternative had not been developed in time for inclusion in this report; however, the impacts of the plan on sediment transport can be evaluated using the sediment budget approach.

The diversion structure should be constructed on the outside of a channel bend so that a minimum of bed material load will be diverted. The design should include a side overflow weir that will exclude normal low flows and bed load. The exclusion of bed load from the covered diversion is important because deposits in the diversion conduit would create conveyance and maintenance problems. For purposes of the sediment impact assessment, it was assumed that the diversion would carry all flood flows greater than $500 \mathrm{cfs}$. It was further assumed that all the bed material load would remain in Fountain Creek. Hydrographs were modified, and the sediment budget calculations provided the percent passage of bed material yield from the upstream reach shown in the following tabulation.

The sediment budget analysis indicates that the diversion project will result in more deposition in Reach 2 downstream from the proposed diversion for the 1 percent chance exceedance hydrograph and for the average annual basis. For the 50 percent chance exceedance hydrograph, there is no difference because no flow is diverted. Significantly more degradation will occur in Reach 4 , downstream from the diversion return point, for the 1 percent chance exceedance hydrograph and the average annual basis. This is due to the reduced sediment supply from upstream with the implementation of the diversion plan. Increased maintenance costs in the existing channel should be included in the design plan for the diversion structure. 


\begin{tabular}{|c|c|c|c|}
\hline \multirow[b]{2}{*}{ Reach } & \multicolumn{3}{|c|}{ Percentage of Sediment from Upstream Reach Passing this Reach } \\
\hline & Average Annual & $\begin{array}{l}50 \text { Percent Chance } \\
\text { Exceedance } \\
\text { Hydrograph }\end{array}$ & $\begin{array}{l}1 \text { Percent Chance } \\
\text { Exceedance } \\
\text { Hydrograph }\end{array}$ \\
\hline \multicolumn{4}{|c|}{ Existing Conditions } \\
\hline 2 & 48 & 62 & 64 \\
\hline 3 & 103 & 98 & 120 \\
\hline 4 & 190 & 170 & 270 \\
\hline 5 & 68 & 81 & 50 \\
\hline \multicolumn{4}{|c|}{ With Diversion } \\
\hline 2 & 25 & 62 & 37 \\
\hline 3 & 82 & 98 & 101 \\
\hline 4 & 450 & 170 & 580 \\
\hline 5 & 68 & 81 & 50 \\
\hline
\end{tabular}




\section{Total Sediment Yield}

\section{Approach}

Calculations of total sediment yield were made for each watershed contributing sediment to Fountain Creek within the study reach. These calculations were made to obtain estimates of sediment volumes for sizing reservoirs and/or debris basins. Estimates of total sediment yields were made for both the 50 percent chance exceedance flood and the 1 percent chance exceedance flood and for average annual conditions.

The total sediment yield is composed of both wash load and bed material load. As defined previously, the wash load is the fine sediment that remains in suspension without exchanging with the bed once it reaches a channel. Wash load sources are the watershed surface, gullies, and the channel bed and banks. The bed material load is the sediment load that actively exchanges with the channel bed as it is transported downstream as either suspended load or bed load. The bed material load capacity is determined by the composition of the bed and the hydraulic properties of the channel.

There is no generally accepted method for calculating total sediment yield. Available techniques require measured sediment deposition or transport data for adjustments to establish coefficients. Because many factors affect the sediment yield, it is generally necessary to have a significant sediment database to refine a technique to the point where it can be used to make reliable predictions. This database does not exist in the Manitou Springs study area. The approach taken in this study was to apply techniques that have been used in somewhat similar watersheds, using limited available data, and then draw some general conclusions about the magnitude and uncertainty of the sediment yield.

Sediment yields from steep mountainous watersheds during a storm event can be estimated using the Los Angeles District Method (USAED, Los Angeles, 1992). This empirical method was developed using data from watersheds in the Southern California Coastal Range. Sediment yields predicted by this method represent sediment trapped in debris basins and consist primarily of coarser sediment sizes. The average annual sediment yield can be predicted using the Pacific Southwest Inter-agency Committee (PSIAC) 
Method (PSIAC 1968). This is also an empirical method based on depositional data from the Pacific southwest.

\section{Los Angeles District Method}

The Los Angeles District Method is based on a statistical analysis of measured deposition in debris basins, hydrologic data, and watershed characteristics. The database for these equations includes that of Tatum (1963) plus additional data collected from debris basins located in the Southern California Coastal Range subsequent to Tatum's work. This method is intended to estimate the debris yield from coastal-draining, mountainous Southern California watersheds. Outside of the recommended application area, careful adjustment of the calculated yields is required.

A total of 350 observations from 80 watersheds were used to develop the following regression equation used to calculate unit debris yield for drainage areas up to 3 square miles:

$$
\begin{aligned}
\log D_{y}=0.65(\log P) & +0.62(\log R R)+0.18(\log A) \\
& +0.12(F F)
\end{aligned}
$$

where

$$
\begin{aligned}
D_{y}= & \text { unit debris yield }, \text { cu } \mathrm{yd} / \text { square mile } \\
P= & \text { maximum } 1 \text {-hour precipitation, in inches, taken to two decimal } \\
& \text { places multiplied by } 100 \\
R R= & \text { relief ratio, } \mathrm{ft} / \text { mile } \\
A= & \text { drainage area, acres } \\
F F= & \text { fire factor }
\end{aligned}
$$

The 50 percent and 1 percent chance exceedance regional 1-hour point rainfalls were obtained from Miller, Frederick, and Tracey (1973). Technical Memorandum NWS HYDRO-40 (NOAA 1984) was used to reduce the point precipitation for a given drainage area, which is the maximum 1-hour precipitation required by Equation 2. It should be noted that one of the limitations of the Los Angeles District Method is that the flood should have at least a 20 percent chance exceedance frequency. Using the 50 percent chance exceedance flood is an extrapolation of the method, and results must be used with caution. The relief ratio is determined as follows: 


$$
R R=\frac{H P-L P}{L_{l s}}
$$

where

$$
\begin{aligned}
& H P=\text { highest point in the watershed taken at the extension of the longest } \\
& \text { stream, } \mathrm{ft} \\
& L P= \\
& L_{l s}=\begin{array}{l}
\text { length of the longest stream up to the highest point in the } \\
\text { watershed, miles }
\end{array}
\end{aligned}
$$

Several of the drainage basins considered in this study have dams. Any sediment produced upstream of the dams would not reach the debris collection site. In this study, the noncontributing areas upstream from dams have been neglected when determining subbasin drainage areas. Fountain Creek upstream from Ruxton Creek has several dams that reduce its drainage area from 70 square miles to 50 square miles, and the drainage area of Ruxton Creek at Fountain Creek is reduced from 18 square miles to 12 square miles. The nondimensional fire factor is found from a set of fire factor curves. These curves are dependent on the size of the drainage area. The first curve (Figure 19) is applicable for a drainage area between 0.1 and 3 square miles. The remaining curves (Figure 20) are for a range of drainage areas from 3 to 200 square miles. When the destruction of the watershed vegetation by fire is not considered, the fire factor is set to 3 , an unburned value. It was considered unlikely that a full or partial burn would be followed by a 1 percent chance exceedance flood. In this instance an unburned fire factor was considered reasonable. To predict sediment yield after a total watershed burn, the 50 percent chance exceedance flood was considered.

The calculated debris yield from Equation 2, in statistical terms, is the expected value. Uncertainty associated with the calculated result can be measured using the standard deviation of the estimate of the expected value. The standard deviation for Equation 2 is $0.465\left(\log \mathrm{D}_{\mathrm{y}}\right)$. It can be stated with 67 percent confidence that the "true" value of debris yield is within one standard deviation of the expected value. It can also be stated with 95 percent confidence that the true debris yield will fall within two standard deviations of the expected value. These statistics are based on the data used to develop the regression equation and assume that any calculated value comes from a watershed with similar geomorphic and hydrologic conditions.

For drainage areas between 3 and 10 square miles, the following regression equation was developed: 


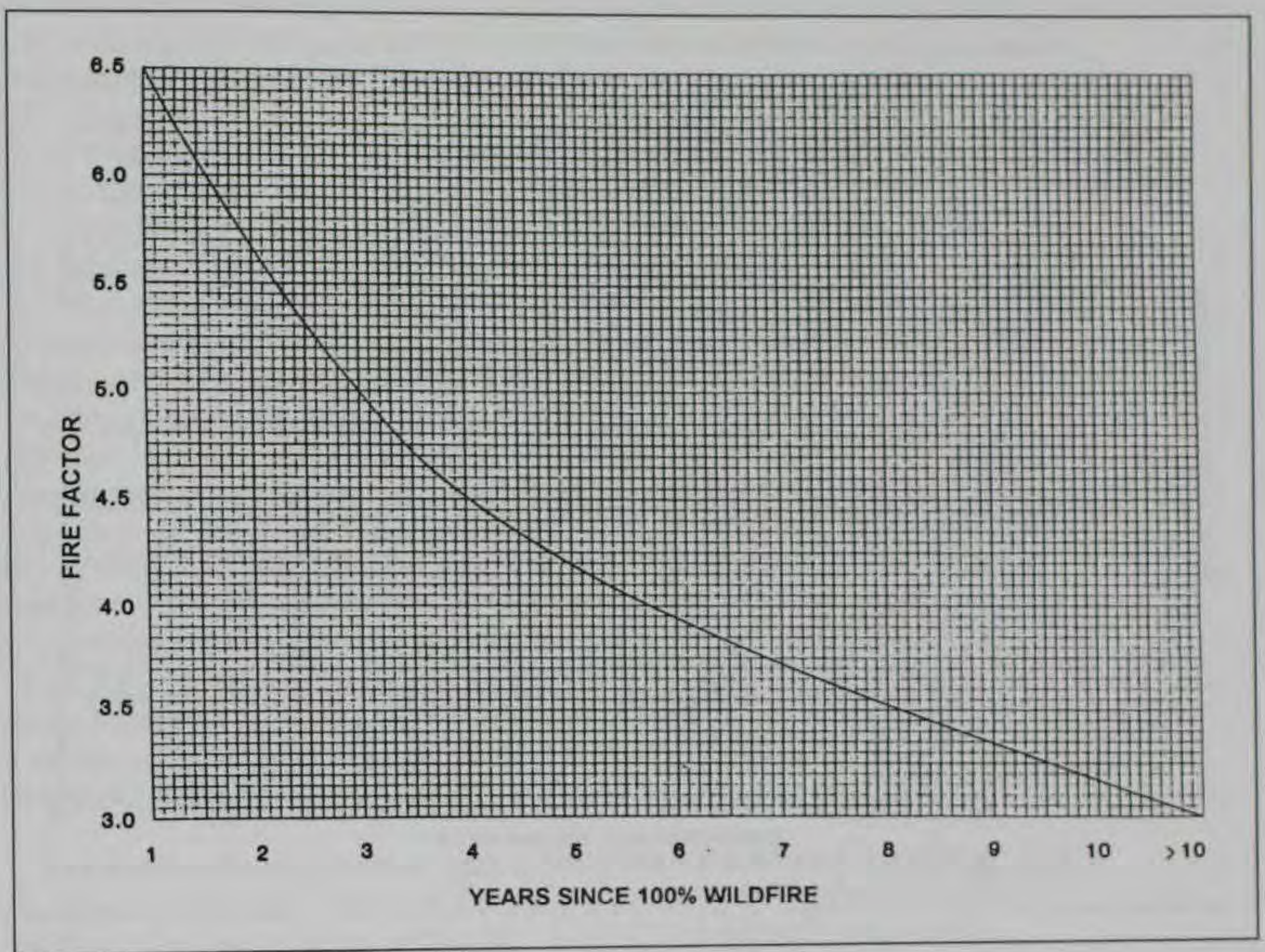

Figure 19. Fire factor curve for watersheds 0.1 to 2.0 square miles

$$
\begin{aligned}
\log D_{y} & =0.85(\log Q)+0.53(\log R R) \\
& +0.04(\log A)+0.22(F F)
\end{aligned}
$$

where $Q$ is the unit peak discharge, cfs/square mile. The unit peak discharge is found by dividing the peak discharge by the drainage area.

The equation for drainage areas between 10 and 25 square miles is:

$$
\begin{aligned}
\log D_{y}=0.88(\log Q) & +0.48(\log R R)+0.06(\log A) \\
& +0.20(F F)
\end{aligned}
$$

When the drainage area is between 25 and 50 square miles the equation is:

$$
\begin{aligned}
\log D_{y}=0.94(\log Q) & +0.32(\log R R)+0.14(\log A) \\
& +0.17(F F)
\end{aligned}
$$




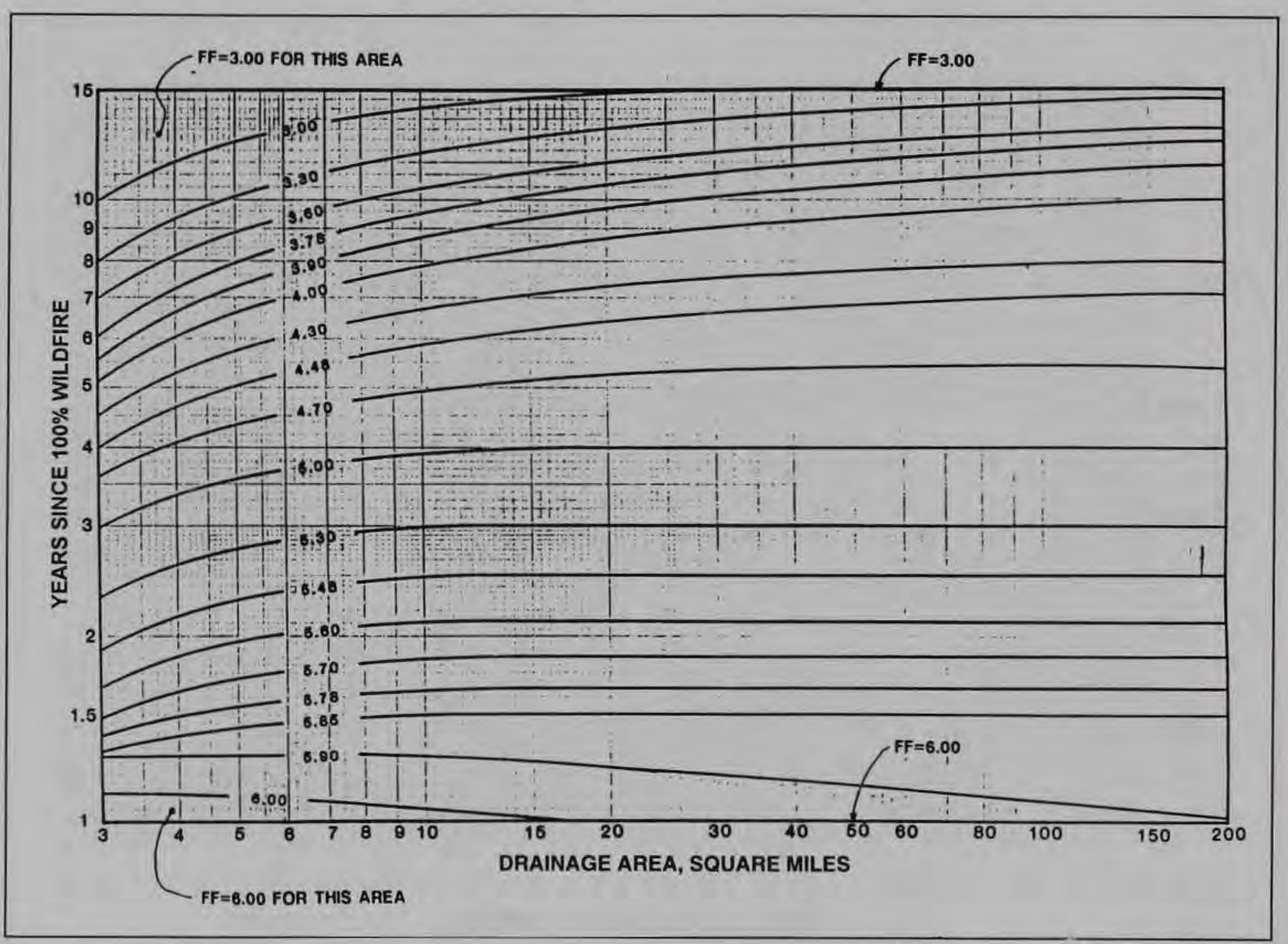

Figure 20. Fire factor curves for watersheds from 3.0 to 200 square miles

For larger drainage areas between 50 and 200 square miles the equation is:

$$
\begin{aligned}
\log D_{y}=1.02(\log Q) & +0.23(\log R R)+0.16(\log A) \\
& +0.13(F F)
\end{aligned}
$$

A total of 187 observations from seven watersheds were used in the development of Equations 4 through 7 . The standard deviation was determined to be $0.242 \log D_{y}$.

Fountain Creek above Ruxton Creek has a drainage area of 50.3 square miles. Because this size is very close to the boundary determining the use of either Equation 6 or 7, in this study both equations were used to calculate the sediment yield. The difference in sediment yield obtained from using Equations 6 and 7 indicates a discontinuity in the system of equations and provides another indication of the uncertainty associated with the technique.

In the development of the Los Angeles District Method regression equations, watersheds with high unit yields were used. Applying this technique to areas with less erosion will overestimate debris yields. This led to the development of the adjustment and transposition (A-T) factor. This factor 
takes into account the unquantifiable geomorphic and geologic parameters that affect debris production. Watersheds in the San Gabriel Mountains of southern California, which provided the data for the regression equations, would have an A-T factor of 1 . Areas that have less debris yield potential would have values less than 1 and those with a greater potential would use a value greater than 1. The Los Angeles District Method provides several techniques for determining the A-T factor. The preferred techniques require data from the subject or nearby watersheds. The required data include measured deposition in debris basins from storms with known runoff or rainfall, average annual rainfall, and sediment yield. When no debris yield data of any kind are available, a technique is used that requires a detailed field analysis identifying geomorphic characteristics of the watershed. As no debris yield data were available for the area under consideration or a neighboring area, the latter method of finding the A-T factor was employed. It should be noted that only a cursory inspection of the catchments was made so that an A-T factor was developed for the study area as a whole and not on an individual watershed basis. A more detailed look at the catchments will be required for a more accurate definition of the A-T factor. Table A3 is a guide for selecting values for different subfactors used to obtain the A-T factor. Assigned values for each category are summed to obtain the A-T factor. The unit debris yield is calculated from the appropriate equation and then multiplied by the A-T factor, producing an adjusted unit debris yield.

The watershed characteristics used to determine the subfactor values are presented in Table A4. Owing to the cursory nature of the catchment inspection for the sediment impact assessment, two A-T factors were determined, one A-T factor representing an average case and one a case with more severe erosion. Assigned subfactors for the A-T factor determination for Fountain Creek and its tributaries can be seen in Table A5. The tabulation on page 32 gives the summary results of sediment yield using the Los Angeles District method.

\section{Pacific Southwest Inter-agency Committee Method (PSIAC)}

This technique was developed to evaluate average annual sediment yield for a variety of conditions found in the Pacific southwest. It is intended for broad planning purposes rather than specific projects where more intensive investigations of sediment yield would be required. A minimum drainage area of 10 square miles has been suggested, but for the reconnaissance level study it has been applied to all the drainage areas irrespective of size. For the smaller drainage areas this would increase the error associated with the calculation.

The PSIAC method places the area under consideration in one of five sediment yield classifications using nine determining factors. The nine factors are geology, soils, climate, runoff, topography, ground cover, land use, upland erosion, and channel erosion and sediment transport. Characteristics of each 
of these factors can be seen in Table A6, with an appropriate rating alongside each. Each of the characteristics has been assessed for its contribution to sediment yield. A high rating is given to a characteristic that prompts sediment yield, and so on for a moderate and low rating. Each rating has been assigned a numerical value that indicates its relative significance. The sum of these numerical values for the nine determining factors results in the yield rating.

\begin{tabular}{|c|c|c|c|c|c|c|}
\hline \multirow[b]{3}{*}{ Stream } & \multicolumn{6}{|c|}{ Total Sediment Yield, Los Angeles District Method } \\
\hline & \multirow{2}{*}{$\begin{array}{l}\text { Flood Event } \\
\text { (Percent } \\
\text { Chance } \\
\text { Exceedance) }\end{array}$} & \multirow{2}{*}{$\begin{array}{l}\text { Drainage } \\
\text { Area } \\
\text { square } \\
\text { miles }\end{array}$} & \multicolumn{2}{|c|}{ Variables } & \multirow{2}{*}{$\begin{array}{l}\text { Unit } \\
\text { Debris } \\
\text { Yield } \\
\text { cu yd/ } \\
\text { square } \\
\text { mile }\end{array}$} & \multirow{2}{*}{$\begin{array}{l}\text { Debris } \\
\text { Volume } \\
\text { cu yd }\end{array}$} \\
\hline & & & $\begin{array}{l}\text { Fire } \\
\text { Factor }\end{array}$ & $\begin{array}{l}\text { A-1 } \\
\text { Factor }\end{array}$ & & \\
\hline Unnamed & $\begin{array}{l}\text { 1, with } \\
\text { no burn }\end{array}$ & 1.4 & 3 & $\begin{array}{l}0.55 \\
0.75\end{array}$ & $\begin{array}{l}15,000 \\
21,000\end{array}$ & $\begin{array}{l}20,000 \\
28,000\end{array}$ \\
\hline Black Canyon Creek & $\begin{array}{l}\text { 1. with } \\
\text { no burn }\end{array}$ & 2.6 & 3 & $\begin{array}{l}0.55 \\
0.75\end{array}$ & $\begin{array}{c}9,600 \\
13,000\end{array}$ & $\begin{array}{l}25,000 \\
34,000\end{array}$ \\
\hline Williams Canyon Creek & $\begin{array}{l}\text { 1. with } \\
\text { no burn }\end{array}$ & 2.7 & 3 & $\begin{array}{l}0.55 \\
0.75\end{array}$ & $\begin{array}{c}9,900 \\
13,000\end{array}$ & $\begin{array}{l}27,000 \\
36,000\end{array}$ \\
\hline Sutherland Creek & $\begin{array}{l}\text { 1. with } \\
\text { no burn }\end{array}$ & 5.2 & 3 & $\begin{array}{l}0.55 \\
0.75\end{array}$ & $\begin{array}{l}13,000 \\
17,000\end{array}$ & $\begin{array}{l}66,000 \\
90,000\end{array}$ \\
\hline Ruxton Creek & $\begin{array}{l}1 \text {, with } \\
\text { no burn }\end{array}$ & 12.1 & 3 & $\begin{array}{l}0.55 \\
0.75\end{array}$ & $\begin{array}{l}10,000 \\
14,000\end{array}$ & $\begin{array}{l}120,000 \\
170,000 \\
\end{array}$ \\
\hline $\begin{array}{l}\text { Fountain Creek } \\
\text { (Equation 6) }\end{array}$ & $\begin{array}{l}\text { 1, with } \\
\text { no burn }\end{array}$ & 50.3 & 3 & $\begin{array}{l}0.55 \\
0.75\end{array}$ & $\begin{array}{l}4,000 \\
5,000\end{array}$ & $\begin{array}{l}200,000 \\
270,000\end{array}$ \\
\hline $\begin{array}{l}\text { Fountain Creek } \\
\text { (Equation 7) }\end{array}$ & $\begin{array}{l}\text { 1, with } \\
\text { no burn }\end{array}$ & 50.3 & 3 & $\begin{array}{l}0.55 \\
0.75\end{array}$ & $\begin{array}{l}3,300 \\
4,600\end{array}$ & $\begin{array}{l}170,000 \\
230,000\end{array}$ \\
\hline Unnamed & $\begin{array}{l}50, \text { with } \\
100 \% \text { burn }\end{array}$ & 1.4 & 6.5 & $\begin{array}{l}0.55 \\
0.75\end{array}$ & $\begin{array}{l}21,000 \\
28,000\end{array}$ & $\begin{array}{l}28,000 \\
38,000\end{array}$ \\
\hline Black Canyon Creek & $\begin{array}{l}50, \text { with } \\
100 \% \text { Burn }\end{array}$ & 2.6 & 6.5 & $\begin{array}{l}0.55 \\
0.75\end{array}$ & $\begin{array}{l}13,000 \\
18,000\end{array}$ & $\begin{array}{l}34,000 \\
46,000\end{array}$ \\
\hline Williams Canyon Creek & $\begin{array}{l}50, \text { with } \\
100 \% \text { burn }\end{array}$ & 2.7 & 6.5 & $\begin{array}{l}0.55 \\
0.75\end{array}$ & $\begin{array}{l}13,000 \\
18,000\end{array}$ & $\begin{array}{l}36,000 \\
49,000\end{array}$ \\
\hline Sutherland Creek & $\begin{array}{l}50, \text { with } \\
100 \% \text { burn }\end{array}$ & 5.2 & 6 & $\begin{array}{l}0.55 \\
0.75\end{array}$ & $\begin{array}{l}1,400 \\
2,000\end{array}$ & $\begin{array}{c}7,500 \\
10,000\end{array}$ \\
\hline Ruxton Creek & $\begin{array}{l}50, \text { with } \\
100 \% \text { burn }\end{array}$ & 12.1 & 6 & $\begin{array}{l}0.55 \\
0.75\end{array}$ & $\begin{array}{l}1,100 \\
1,400\end{array}$ & $\begin{array}{l}13,000 \\
17,000\end{array}$ \\
\hline $\begin{array}{l}\text { Fountain Creek } \\
\text { (Equation 6) }\end{array}$ & $\begin{array}{l}50, \text { with } \\
100 \% \text { burn }\end{array}$ & 50.3 & 6 & $\begin{array}{l}0.55 \\
0.75\end{array}$ & $\begin{array}{l}370 \\
510\end{array}$ & $\begin{array}{l}19,000 \\
25,000\end{array}$ \\
\hline $\begin{array}{l}\text { Fountain Creek } \\
\text { (Equation 7) }\end{array}$ & $\begin{array}{l}50, \text { with } \\
100 \% \text { burn }\end{array}$ & 50.3 & 6 & $\begin{array}{l}0.55 \\
0.75\end{array}$ & $\begin{array}{l}170 \\
240\end{array}$ & $\begin{array}{c}8,700 \\
12,000\end{array}$ \\
\hline
\end{tabular}


A check procedure is incorporated into the technique. A high sum of values A through $\mathrm{G}$, in Table A6, should result in high summed values of $\mathrm{H}$ and $\mathrm{I}$. If this is not the case, then either unusual erosion conditions exist or factors A-G should be reevaluated. The conversion of the yield rating is done through a table that links the rating to a class and an average annual yield as shown in the following tabulation.

\begin{tabular}{||l|l|l||}
\hline Rating & Classification & $\begin{array}{l}\text { Sediment Yield } \\
\text { acre-feet/square mile }\end{array}$ \\
\hline \hline$>100$ & 1 & $>3.0$ \\
\hline $75-100$ & 2 & $1.0-3.0$ \\
\hline $50-75$ & 3 & $0.5-1.0$ \\
\hline $25-50$ & 4 & $0.2-0.5$ \\
\hline $0-25$ & 5 & $<0.2$ \\
\hline
\end{tabular}

The ratings assigned to each of the nine determining factors for this sediment impact assessment can be seen in Table A7. This technique was carried out with only a cursory viewing of the watersheds, so that although individual subbasin evaluation was possible, it was done on an elementary level. For a more detailed and accurate employment of this technique a more detailed investigation of the catchments would be required. More error will be inherent in the calculations for the drainage areas that are less than 10 square miles as they are smaller than the limit imposed by this technique. The results for the average annual total sediment yield follow:

\begin{tabular}{||l|l|l||}
\hline Stream & Rating & $\begin{array}{l}\text { Total Sediment Yield } \\
\text { PSIAC Method } \\
\text { acre-feet/square mile }\end{array}$ \\
\hline \hline Unnamed Creek & 45 & $0.2-0.5$ \\
\hline Black Canyon Creek & 35 & $0.2-0.5$ \\
\hline Williams Canyon Creek & 42.5 & $0.2-0.5$ \\
\hline Sutherland Creek & 45 & $0.2-0.5$ \\
\hline Ruxton Creek & 45 & $0.2-0.5$ \\
\hline Fountain Creek & 37.5 & $0.2-0.5$ \\
\hline
\end{tabular}

\section{Reservoir Survey Comparisons}

Reservoir surveys in neighboring watersheds can be used to obtain generalized regional average annual sediment yields. Results are gathered by the Federal Interagency Subcommittee on Sedimentation in several publications entitled "Sediment Deposition in U.S. Reservoirs" (U.S. Department of 
Agriculture 1978; Subcommittee on Sedimentation 1983, 1992). Records for central and southern Colorado and the northern part of New Mexico between 1960 and 1985 provide some basis for regional comparisons. Watersheds associated with the reservoir surveys are not necessarily similar to Fountain Creek watershed. Therefore, the regional sediment yields should be used only as a guideline. Several small catchments between 0.18 and 0.44 square mile were measured on Fort Carson Military Base, Colorado. The period of record varied between 25 and 38 years. The average annual sediment yield range for these reservoirs over the period of record was between 0.05 and 0.57 acre-foot/square mile. Mud Gulch Reservoir near Canon City, CO, has a catchment of 2.2 square miles and has an annual sediment yield of 0.11 acre-foot/square mile over a 10-year period of record. The Abiquiu Reservoir in New Mexico is large, with a catchment of 1,254 square miles, and has an average annual sediment yield over a 15 -year period of record of 0.7 acre-foot/square mile.

Average annual sediment yields for the study catchments determined using the PSIAC method were 0.2 to 0.5 acre-foot/square mile. These values are within the range of data from the regional reservoir sediment yield surveys.

\section{Total Sediment Yield Results}

The sediment volumes predicted by the Los Angeles District and PSIAC methods are compared in the following tabulation:

\begin{tabular}{|c|c|c|c|c|c|}
\hline \multirow[b]{4}{*}{ Stream } & \multicolumn{5}{|c|}{ Calculated Sediment Yield } \\
\hline & \multicolumn{4}{|c|}{ LA District Method } & \multirow{3}{*}{$\begin{array}{l}\text { PSIAC Method } \\
\text { Average Annual } \\
\text { Sediment Volume } \\
\text { cu yd }\end{array}$} \\
\hline & \multicolumn{2}{|c|}{$\begin{array}{l}\text { Sediment Volume } \\
1 \text { percent Exceedance } \\
\text { No Burn } \\
\text { cu yd }\end{array}$} & \multicolumn{2}{|c|}{$\begin{array}{l}\text { Sediment Volume } \\
50 \text { percent } \\
\text { Exceedance } \\
100 \% \text { Burn } \\
\text { cu yd }\end{array}$} & \\
\hline & $\begin{array}{l}\text { A-T } \\
\text { Factor } \\
0.55 \\
\end{array}$ & $\begin{array}{l}\text { A-T } \\
\text { Factor } \\
0.75 \\
\end{array}$ & $\begin{array}{l}\text { A-T } \\
\text { Factor } \\
0.55 \\
\end{array}$ & $\begin{array}{l}\text { A-T } \\
\text { Factor } \\
0.75 \\
\end{array}$ & \\
\hline Unnamed & 20,000 & 28,000 & 28,000 & 38,000 & $450-1,100$ \\
\hline Black Canyon Creek & 25,000 & 34,000 & 34,000 & 46,000 & $840-2,100$ \\
\hline Williams Canyon Creek & 27,000 & 36,000 & 36,000 & 49,000 & $870-2,200$ \\
\hline Sutherland Creek & 66,000 & 90,000 & 7,500 & 10,000 & $1,700-4,200$ \\
\hline Ruxton Creek & 120,000 & 170,000 & 13,000 & 17,000 & $3,900-9,800$ \\
\hline $\begin{array}{l}\text { Fountain Creek } \\
\text { (Equation 6) }\end{array}$ & 200,000 & 270.000 & 19,000 & 25,000 & \multirow[t]{2}{*}{$16,000-41,000$} \\
\hline $\begin{array}{l}\text { Fountain Creek } \\
\text { (Equation 7) }\end{array}$ & 170,000 & 230,000 & 8,700 & 12,000 & \\
\hline
\end{tabular}


Sediment yields calculated using the Los Angeles District method with the lower A-T factor can be considered as an average estimate. The yields calculated using the higher A-T value should be considered as an upper range solution. A greater range in results may be obtained using the standard deviation associated with each regression equation. It needs to be repeated that only a preliminary assessment of the A-T factor was possible for the sediment impact assessment and that the resultant volumes need to be viewed with this in mind. As Fountain Creek is on the boundary of the drainage area restraints for two equations, both have been used. This results in a low and high sediment volume for each A-T factor, or an average may be considered. It is interesting to note that the smaller catchments, Unnamed, Black Canyon, and Williams Canyon Creeks, have a higher 50 percent exceedance volume than the 1 percent exceedance volume. This is the direct result of the effects that the 100 percent burn has on the availability of debris and sediment. Catchments that have experienced no burn have good vegetation so that the surfaces are protected. The larger catchments, Sutherland, Ruxton, and Fountain Creeks, have much lower unit sediment yields for the 50 percent exceedance flood, even with 100 percent burn, due to the relatively lower average rainfall that occurs over the larger drainage areas during the 50 percent exceedance flood. The increase in sediment potential from the burn is overshadowed by the small 50 percent chance exceedance unit discharge. These larger catchments also show lower predicted unit sediment yields for the 1 percent chance exceedance flood. This agrees with other studies that show catchments with larger drainage areas generally exhibit a smaller delivery ratio than smaller ones. Larger catchments will usually have a lower overall slope, smaller upland sediment sources, and more opportunity for deposition, all of which reduces the potential sediment yield.

Most of the sediment volume produced from the Unnamed, Williams Canyon, and Ruxton Creeks will not reach Fountain Creek because pipes and culverts carry the flow of these creeks upstream from their confluence with Fountain Creek. These pipes constrict the channels and will force flood flow into the streets. Bed load remaining in the creeks will deposit, further reducing conveyance in the creek and causing additional flooding. Sutherland Creek has a constrictive culvert just upstream from its confluence with Fountain Creek that would stop the majority of the sediment coming down Sutherland Creek and send the flow out into the streets. Black Canyon Creek is the only tributary that could deliver sediment unobstructed into Fountain Creek.

A more detailed watershed investigation is required to give a more reliable estimate of the sediment yield calculated using both the Los Angeles District and the PSIAC Methods during the next level of planning study. A detailed field survey would be required of each subbasin. This would involve several different areas where expertise would be required: geology, soils, geomorphology, river hydraulics, vegetation, and mountain hydrology. 


\section{Debris Flow Potential}

\section{Determining Factors}

Debris flows are the main process responsible for the formation of alluvial fans/debris cones at the base of mountain valleys. These features are generally composed of a poorly sorted mixture. Debris flows are a form of mass wasting and occur relatively infrequently. The amount of fluid in a debris flow may be only 20 percent or less. The complementing amount of solid material can vary between 25 and 70 or 80 percent.

The occurrence of debris flows is governed by several factors:

a. The composition of the material in question (there needs to be sufficient unconsolidated debris and a high clay conten $i$ ).

$b$. The underlying beds and the dip of the bedding planes.

c. The steepness of slopes.

d. The hydrological situation.

Conclusions to date reveal that debris flows occur on sediment beds in mountain canyons when the slopes are steeper than 15 degrees $(0.27)$ and stop movement when the slopes are less than 3 degrees $(0.05)$. The finer particles within the debris flows may continue movement down to flatter slopes as bed load and suspended load. Progressively smaller basins with steep slopes are more suitable to debris flows than their larger counterparts because thunderstorms deliver proportionally larger volumes of water on smaller basins and their steeper side slopes, resulting in instability of surficial deposits, making them ready for transport.

Gagoshidze (1969) summarized the requirements for debris flows in the Soviet Union:

a. Basins should have a predominance of rocks rich in clay forming aluminosilicates and clay minerals (clay, argillites, clay shale, gneisses, granitoid rocks, volcanic ash, tuff, polymictic sandstone, etc.). 
$b$. The basins should be small, $<0.62$ square mile per mile of the length of the main watercourse.

c. The main watercourse should be short, $<18.6$ miles to the debris cone.

$d$. The basin slopes should be about 40 degrees or more, the average slope of the main watercourse to the deposit site should be at least 0.10 , the channel slope of any lateral tributaries should be greater than the main watercourse, and the first part of the debris cone should have slopes of at least $0.04-0.05$.

e. There should be sharp delineation between the source areas, transport reaches, and deposition sites.

Antecedent conditions have been found to be important. A rainfall of 0.25 in. per hour in an area where the total seasonal antecedent rainfall was $10 \mathrm{in}$. is the threshold for soil slip and debris flows in the Santa Monica Mountains of Southern California. Costa and Jarrett (1981) concluded that debris flows can occur during most rainfall events provided sufficient material of a poorly sorted nature is available on side slopes ready for movement.

Availability of material is an important factor affecting the frequency of debris flow events. If large amounts of material have recently been removed by a large runoff event, then the basin is not able to produce debris flows again until sufficient time has passed to replenish loose material for transport. This is accomplished through the natural processes of weathering, mass wasting, and landslides. In larger basins the data seem to suggest that debris flows do not occur as frequently near the downstream end of a basin. Old debris flow deposits may be future sources of debris flow or may be remobilized during future events.

Another factor that affects the potential for debris flows is the condition of the watershed. If a burn has occurred in the area recently, the potential increases as there is an increase in source sites. Extensive logging, cattle grazing, and road construction will also increase the possibility for debris flows. Vegetation cover is a major factor in the prevention of debris flows by reducing the debris accumulation and deceasing the peak discharge. Costa and Jarrett (1981) suggested that the timberline elevation of 7,000-8000 ft in the Rocky Mountains, Colorado, may be the divide between two environments where hydrologic processes may differ. Below this elevation, intense rainfalls over large areas are frequent and may cause large waterfloods with sediment loads that are quite high. Above this elevation, intense rainfalls are less frequent and debris flows may occur as well as waterfloods.

\section{Analysis of Debris Flow Potential}

Available guidelines describing the prerequisites for debris flow are listed in the following tabulation: 


\begin{tabular}{|c|c|c|c|c|c|c|c|}
\hline Creek & Rock Type & $\begin{array}{l}\text { Size } \\
\text { square } \\
\text { miles per } \\
\text { mile }\end{array}$ & $\begin{array}{l}\text { Creek } \\
\text { Length } \\
\text { miles }\end{array}$ & $\begin{array}{l}\text { Creek } \\
\text { Slope }\end{array}$ & $\begin{array}{l}\text { Tribu- } \\
\text { tary } \\
\text { Slope } \\
\text { Steeper }\end{array}$ & $\begin{array}{l}\text { Debris } \\
\text { Cone } \\
\text { Slope }\end{array}$ & $\begin{array}{l}\text { Sharp } \\
\text { Delineation }\end{array}$ \\
\hline $\begin{array}{l}\text { Unnamed } \\
\text { Creek }\end{array}$ & \multirow{6}{*}{$\begin{array}{l}\text { Precambrian } \\
\text { igneous } \\
\text { and } \\
\text { metamorphic } \\
\text { rocks: } \\
\text { granites, schists, } \\
\text { gneisses. } \\
\text { East } \\
\text { narrow } \\
\text { zone } \\
\text { of } \\
\text { Paleozoic } \\
\text { and } \\
\text { Mesozoic } \\
\text { sedimentary } \\
\text { rocks. }\end{array}$} & 0.90 & 1.50 & 0.29 & & None & Yes \\
\hline $\begin{array}{l}\text { Black } \\
\text { Canyon } \\
\text { Creek }\end{array}$ & & 0.87 & 2.98 & 0.13 & Yes & None & Yes \\
\hline $\begin{array}{l}\text { Williams } \\
\text { Canyon } \\
\text { Creek }\end{array}$ & & 0.63 & 4.25 & 0.12 & Yes & None & Yes \\
\hline $\begin{array}{l}\text { Sutherland } \\
\text { Creek }\end{array}$ & & 1.27 & 4.06 & 0.17 & Yes & None & Yes \\
\hline $\begin{array}{l}\text { Ruxton } \\
\text { Creek }\end{array}$ & & 2.03 & 5.93 & 0.18 & $\begin{array}{l}\text { Most } \\
\text { Yes }\end{array}$ & None & Yes \\
\hline $\begin{array}{l}\text { Fountain } \\
\text { Creek }\end{array}$ & & 3.92 & 12.83 & 0.05 & $\begin{array}{l}\text { Most } \\
\text { Yes }\end{array}$ & None & Yes \\
\hline
\end{tabular}

Because no detailed field investigation was conducted for the sediment impact assessment, several assumptions were made regarding the prerequisites for debris flow. Firstly, the rock type for the entire Fountain Creek drainage area was based on observations at a few sites and assumed to be homogeneous throughout. The tributary slopes are, on the whole, steeper than the watercourse slopes, and the assumption was made that there was sharp delineation between the source, transport, and deposition sites. Few debris source sites and no debris cones were observed during the cursory field investigation. The channel slope and that of the tributaries were calculated using the blue lines, which represents a definable channel, from a 1:24,000 quad map and the elevations taken at the highest point at the end of the blue line and the lowest elevation at the potential debris site.

The observed rock type of the drainage area is in a category that can produce debris. The main watercourses of the tributaries are short and the channel slopes are steep enough to support movement of debris flows. This is not the case for Fountain Creek itself. These factors suggest that debris flows are possible in the tributary watersheds; however, no debris cone deposits were observed and the drainage basins are larger than 0.62 square mile/mile. The area is well vegetated and no burn has occurred in the area. These factors suggest debris flows are possible but unlikely under present conditions unless a severe storm event occurs or the area undergoes a burn, logging, or road construction. A detailed field reconnaissance is required to fully assess debris flow potential. 


\section{Summary and Recommendations}

A sediment impact assessment was conducted for Fountain Creek through Manitou Springs, CO. The purpose of the study was to identify the magnitude of sediment problems that might be associated with proposed floodcontrol projects and to recommend appropriate sedimentation studies for the next level of planning study. This was accomplished using a sediment budget approach to evaluate channel stability in terms of aggradation and degradation and a total sediment yield analysis to provide sediment volumes for sizing reservoirs and/or debris basins. The sediment impact assessment provides only qualitative results appropriate for evaluating alternatives at the reconnaissance level planning study.

Available data were used in the sediment impact assessment. Hydraulics were based on an existing HEC-2 backwater model prepared by the Albuquerque District. Reach-averaged values for hydraulic parameters were obtained using the SAM hydraulic design package. Hydrology used included the 1 percent and 50 percent chance exceedance floods, as determined by the Albuquerque District, and a flow duration curve developed from a stream gauge on Fountain Creek. Bed material gradations were based on two samples taken to be representative of the surface and subsurface of Fountain Creek in the study reach.

Bed material sediment yield was calculated using the flow durationsediment discharge-rating curve method. Bed material sediment yield is the sediment load primarily responsible for channel stability. Sediment transport was calculated using three different sediment transport equations to obtain a reasonable range of possible sediment transport rates. Calculated sediment yields at the upstream end of the study reach for the 1 percent chance exceedance hydrograph varied between 4,500 and $10,200 \mathrm{cu}$ yd. Calculated sediment yields for the 50 percent chance exceedance hydrograph varied between 310 and $920 \mathrm{cu}$ yd. Average annual yield varied between 90 and $380 \mathrm{cu}$ yd. These values are very approximate due to the limited data defining the character of the streambed and the variability of hydraulic characteristics along the creek. 
The sediment budget analysis demonstrated the variability in sediment transport capacity through Manitou Springs. A supply reach at the upstream end of the study reach was assigned. Fountain Creek was assumed to be in equilibrium in the supply reach, so that sediment load was equal to the sediment transport capacity. Aggradation and degradation tendencies were determined for upper, middle, and lower reaches of Fountain Creek. Both degradation and aggradation were predicted through Manitou Springs during floods and on an average annual basis. Between 52 and 36 percent of the sediment load delivered from the supply reach should deposit in the upper reach, which includes the main commercial district of Manitou Springs. This deposition is caused by loss of sediment transport capacity due to backwater from constrictions and channel obstructions. The deposition will reduce channel conveyance and cause maintenance problems. In the middle reach, where there are fewer constrictions and channel obstructions, the sediment budget analysis predicted degradation. This will occur because sediment is trapped in the upper reach, reducing sediment inflow to the middle reach to a point where it is less than the sediment transport capacity. Finally, in the lower reach, aggradation is predicted due to reduction in channel slope. The sediment budget analysis provides an estimate of the magnitude of aggradation and degradation problems. These data should be included when determining maintenance costs for both the existing channel and proposed alternatives.

One flood-control alternative was evaluated for its impact on sedimentation in Fountain Creek. Diverting all flood flows over $500 \mathrm{cfs}$ just downstream from Park Avenue would result in significantly more deposition in Fountain Creek downstream from the diversion in the commercial district of Manitou Springs. In addition, much greater degradation was predicted downstream from U.S. Highway 24 where the diverted flow would be returned to Fountain Creek. This does not necessarily render the proposal infeasible, but additional maintenance costs will be expected.

The sediment impact assessment included calculated estimates of total sediment yield for each watershed within the study area. Total sediment yield includes the wash load supplied from the watershed and the bed material load, which is governed by the characteristics of the streambed and the flow. Average annual total sediment yield and the total sediment yield from two storm events were calculated. The storm events included the 1 percent and the 50 percent chance exceedance floods. The 50 percent chance exceedance flood was assumed to take place over a completely burned watershed. The calculated sediment volumes may be used to size reservoirs and/or debris basins during the reconnaissance level planing study. Maximum calculated total sediment yields for the 1 percent and the 50 percent chance exceedance floods are 13,000 and $28,000 \mathrm{cu} y \mathrm{~d} / \mathrm{square}$ mile, respectively. The highest yield rate was for the smallest drainage area. Maximum calculated total sediment yield for the storm events considered from Fountain Creek ranged between 4,600 and 5,000 cu yd/square mile. Average annual sediment yield was calculated to range between 0.2 and 0.5 acre-foot/square mile for Fountain Creek and all the tributaries. 
The potential for debris flow from the tributaries was investigated for the sediment impact assessment. Although some of the watershed characteristics that produce debris flows were identified in the Fountain Creek tributaries, there was no evidence of historical debris flows observed during the limited field reconnaissance. The preliminary conclusion is that debris flows are possible, but unlikely unless the watershed is burned or a severe rainfall event occurs. Future planning studies should include a more detailed study by a geologist and geomorphologist.

Due to the variability in the sediment transport capacity in Fountain Creek, even the existing channel will be unstable during flood conditions. A more detailed sediment study is recommended for the next level of planning study. The detailed study should include a thorough channel bed inventory, identifying both surface and subsurface gradations and bedrock outcrops along Fountain Creek. It is expected that the bed material gradations will vary longitudinally through the study reach. Special care should be taken to identify bed conditions at locations where degradation is predicted. Locations and reliability of channel bed stabilizers should also be determined. The cross-section definition in the HEC-2 backwater model used in this study is generally inadequate for a feasibility level channel stability or sedimentation study. More detailed surveys of cross-section geometry will be required at the next level of planning study. New, more detailed topographic mapping is available and will provide better geometric definition. However, field surveys will still be required to supplement the topographic data. Much better quantitative estimates for sediment deposition and scour, for both existing conditions and alternative designs, can be obtained using the HEC-6 numerical sedimentation model. This model accounts for variable armoring and for the variation in channel cross-sectional areas. Careful adjustment of the model would produce a more reliable estimate of bed material transport through Manitou Springs. The model should be adjusted to reasonably replicate existing conditions, i.e., relatively small changes during a 50 percent chance exceedance hydrograph. A reliable sediment transport equation would need to be identified. Measured sediment transport data from similar streams in the region could be used to select a sediment transport equation.

The sediment yield estimates were calculated using very limited watershed data. If a storage option is pursued in the next level of planning study, a much more detailed investigation of the watershed will be required and more refined calculations made. Input for the more detailed sediment yield study should be obtained from several disciplines including geology, soils, hydraulics, and hydrology.

The following tasks are identified for a more detailed sedimentation study of Fountain Creek:

\section{a. Channelization/Diversion Alternatives}

(1) Channel bed inventory 
(a) Bed material sampling program

(b) Location of hard points and bedrock outcrops

(c) Location, dimensions, and stability of grade control structures

(2) Development of geometric model
(a) Cross-section layout based on locations of grade control
(b) Field surveys

(3) Selection of sediment transport equation
(a) Locate and analyze measured sediment data from similar stream
(b) Evaluate sediment transport equations

(4) Develop HEC-6 model of existing conditions
(a) Adjust model to simulate existing conditions for 50 percent chance exceedance flood
(b) Simulate 1 percent chance exceedance flood
(c) Long-term simulation

(5) Evaluate alternatives

(a) Simulate 50 and 1 percent chance exceedance floods (b) Perform a long-term simulation to determine maintenance
requirements

\section{b. Storage Alternatives}

(1) Sediment yield from watershed
(a) Determine watershed characteristics
(b) Use at least two methods to calculate average annual sediment yields

(2) More detailed study for debris flow potential 


\section{References}

Costa, J. E., and Jarrett, R. D. (1981). "Debris flows in small mountain stream channels of Colorado and their hydrologic implication," Bulletin of the Association of Engineering Geologists XVIII (3), 309-322.

Einstein, Hans A. (1950). "The bed load function for sediment transportation in open channel flow," Technical Bulletin No. 1026, U.S.

Department of Agriculture, Soil Conservation Service, Washington DC.

Gagoshidze, M. S. (1969). "Mud flows and floods and their control," Soviet Hydrology: Selected Papers, Issue No. 4, 410-422.

Gessler, Johannes. (1971). "Beginning and ceasing of sediment motion." River mechanics. Hseih W. Shen, ed., Vol I, Chapter 7, Fort Collins, $\mathrm{CO}, 7-1$ through 7-22.

Headquarters, U.S. Army Corps of Engineers. (1989). "Sediment investigation of rivers and reservoirs," Engineer Manual 1110-2-4000, Washington, DC.

Mears, A. I. (1977). "Debris-flow hazard analysis and migration. An example from Glenwood Springs, Colorado," Information sheet 8 , Colorado Geological Survey, Denver, CO.

Miller, J. F., Frederick, R. H., and Tracey, R. J. (1973). PrecipitationFrequency Atlas of the Western United States; Vol III: Colorado, National Oceanic and Atmospheric Administration, National Weather Service, Silver Spring, MD.

National Oceanic and Atmospheric Administration. (1984). "Depth-area ratios in the semi-arid southwest United States," Technical Memorandum NWS HYDRO-40, U.S. Department of Commerce, Silver Spring, MD.

Pacific Southwest Inter-agency Committee. (1968). "Report of the Water Management Subcommittee on factors affecting sediment yield in the Pacific Southwest area and evaluation of measures for reduction of erosion and sediment yield," Recommendations of the Water Management 
Subcommittee Sedimentation Task Force, Pacific Southwest Inter-agency Committee.

Subcommittee on Sedimentation. (1983), "Sediment deposition in U.S. reservoirs, summary of data reported 1976-80," Interagency Advisory Committee on Water Data, published by U.S. Department of Interior, Geological Survey, Office of Water Data Coordination, Reston, VA.

. (1992). "Sediment deposition in U.S. reservoirs, summary of data reported 1981-85," Interagency Advisory Committee on Water Data, published by U.S. Department of Interior, Geological Survey, Office of Water Data Coordination, Reston, VA.

Takahashi, T. (1981). "Debris flow," Annual Review of Fluid Mechanics 13, 547-560.

Tatum, Fred E. (1963). "A new method of estimating debris-storage requirements for debris basins." Proceedings of the Second Federal Interagency Sedimentation Conference, Jackson, MS, January 28-February 1, 1963. USDA-ARS Miscellaneous Publication No. 970, U.S. Department of Agriculture, Washington, DC.

Thomas, William A., Copeland, Ronald R., Raphelt, Nolan K., and McComas, Dinah N. "User's manual for the Hydraulic Design Package for Channels - SAM" (in preparation), U.S. Army Engineer Waterways Experiment Station, Vicksburg, MS.

Thornbury, W. D. (1965). Regional geomorphology of the United States, Wiley, New York.

U.S. Army Engineer District, Albuquerque. (1974). "Flood plain information: Fountain Creek, Colorado Springs, Manitou Springs, Colorado," Albuquerque, New Mexico.

, Albuquerque. (1994). "Manitou Springs Reconnaissance Study, Hydrology" (in preparation), Appendix A, Albuquerque, NM.

U.S. Army Engineer District, Los Angeles. (1992). "Debris Method - Los Angeles District Method for prediction of debris yield," Los Angeles, CA.

U.S. Army Engineer Hydrologic Engineering Center. (1981). "HEC-1, flood hydrograph package, user's manual," Davis, CA.

. (1990). "HEC-2, water-surface profiles, user's manual," Report CPD-2A, Davis, CA.

. (1993). "HEC-6: Scour and deposition in rivers and reservoirs, user's manual," Davis, CA. 
U.S. Department of Agriculture. (1978). "Sediment deposition in U.S. reservoirs: Summary of data reported through 1975," Miscellaneous Publication No. 1362, Washington, DC.

Wolman, M.G. (1954). "A method of sampling coarse river-bed material," American Geophysical Union Transactions 35 (6), 951-956. 


\section{Appendix A Sediment Yield Tables}




\begin{tabular}{|c|c|c|c|}
\hline \multicolumn{4}{|c|}{$\begin{array}{l}\text { Table A1 } \\
\text { Comparison of Sediment Transport Equations, Sediment Yield, } \\
\text { Upstream Supply Reach }\end{array}$} \\
\hline \multirow[b]{2}{*}{ Sediment Transport Equation } & \multicolumn{3}{|c|}{ Sediment Yield, cu yd } \\
\hline & Average Annual & $\begin{array}{l}1 \text { percent } \\
\text { Exceedance } \\
\text { Hydrograph }\end{array}$ & $\begin{array}{l}50 \text { percent } \\
\text { Exceedance } \\
\text { Hydrograph }\end{array}$ \\
\hline \multicolumn{4}{|c|}{ Bed Load } \\
\hline Meyer-Peter and Müller & 2,200 & 3,600 & 810 \\
\hline Parker & 70 & 4,200 & 270 \\
\hline Einstein Bed Load & 520 & 2,300 & 360 \\
\hline Schoklitsch & 280 & 2,500 & 420 \\
\hline \multicolumn{4}{|c|}{ Total Bed Material Load } \\
\hline Yang & 150 & 10,200 & 660 \\
\hline Einstein Total Load & 560 & 6,700 & 520 \\
\hline Ackers-White & 90 & 4,500 & 310 \\
\hline Toffaleti-Schoklitsch & 380 & 7,100 & 920 \\
\hline Laursen-Copeland & 3,500 & 55,000 & 5,800 \\
\hline Englund-Hansen & 1.500 & 55,000 & 2,900 \\
\hline
\end{tabular}




\begin{tabular}{|c|c|c|c|c|c|c|}
\hline \multicolumn{7}{|c|}{$\begin{array}{l}\text { Table A2 } \\
\text { Calculated Sediment Yields, All Reaches }\end{array}$} \\
\hline & \multicolumn{2}{|c|}{ Average Annual } & \multicolumn{2}{|c|}{$\begin{array}{l}50 \text { Percent Chance } \\
\text { Exceedance }\end{array}$} & \multicolumn{2}{|c|}{$\begin{array}{l}1 \text { Percent Chance } \\
\text { Exceedance }\end{array}$} \\
\hline & $\begin{array}{l}\text { cubic } \\
\text { yards }\end{array}$ & $\begin{array}{l}\text { Percent of } \\
\text { Upstream }\end{array}$ & $\begin{array}{l}\text { cubic } \\
\text { yards }\end{array}$ & $\begin{array}{l}\text { Percent of } \\
\text { Upstream }\end{array}$ & $\begin{array}{l}\text { cubic } \\
\text { yards }\end{array}$ & $\begin{array}{l}\text { Percent of } \\
\text { Upstream }\end{array}$ \\
\hline \multicolumn{7}{|c|}{ Supply Reach } \\
\hline Yang & 150 & & 660 & & 10,200 & \\
\hline $\begin{array}{l}\text { Ackers- } \\
\text { White }\end{array}$ & 93 & & 310 & & 4,500 & \\
\hline $\begin{array}{l}\text { Toffaleti- } \\
\text { Schoklitsch }\end{array}$ & 380 & & 920 & & 7,100 & \\
\hline \multicolumn{7}{|c|}{ Reach 2} \\
\hline Yang & 85 & 57 & 420 & 64 & 6,400 & 63 \\
\hline $\begin{array}{l}\text { Ackers: } \\
\text { White }\end{array}$ & 42 & 45 & 190 & 61 & 2,900 & 64 \\
\hline $\begin{array}{l}\text { Toffaleti- } \\
\text { Schoklitsch }\end{array}$ & 157 & 41 & 580 & 62 & 4,700 & 66 \\
\hline \multicolumn{7}{|c|}{ Reach 3} \\
\hline Yang & 93 & 109 & 410 & 98 & 7,600 & 118 \\
\hline $\begin{array}{l}\text { Ackers- } \\
\text { White }\end{array}$ & 44 & 105 & 180 & 97 & 3,400 & 116 \\
\hline $\begin{array}{l}\text { Toffaleti- } \\
\text { Schoklitsch }\end{array}$ & 150 & 96 & 570 & 98 & 5,900 & 126 \\
\hline \multicolumn{7}{|c|}{ Reach 4} \\
\hline Yang & 150 & 160 & 680 & 166 & 20,000 & 260 \\
\hline $\begin{array}{l}\text { Ackers- } \\
\text { White }\end{array}$ & 81 & 184 & 310 & 170 & 8,600 & 255 \\
\hline $\begin{array}{l}\text { Toffaleti- } \\
\text { Schoklitsch }\end{array}$ & 320 & 213 & 990 & 174 & 18,000 & 305 \\
\hline \multicolumn{7}{|c|}{ Reach 5} \\
\hline Yang & 110 & 74 & 560 & 82 & 9,500 & 48 \\
\hline $\begin{array}{l}\text { Ackers- } \\
\text { White }\end{array}$ & 55 & 68 & 250 & 80 & 4,200 & 48 \\
\hline $\begin{array}{l}\text { Toffaleti- } \\
\text { Schoklitsch }\end{array}$ & 200 & 63 & 790 & 80 & 9,600 & 53 \\
\hline
\end{tabular}




\begin{tabular}{|c|c|c|c|c|c|}
\hline \multicolumn{6}{|c|}{$\begin{array}{l}\text { Table A3 } \\
\text { Los Angeles District A-T Factor Table }\end{array}$} \\
\hline & \multicolumn{5}{|c|}{ A-T Subfactor } \\
\hline & 0.25 & 0.20 & 0.15 & 0.10 & 0.05 \\
\hline \multicolumn{6}{|c|}{ Subfactor Group 1: Parent Material } \\
\hline Folding & Severe & $\begin{array}{l}\text { Moderat } \\
\text { e to } \\
\text { Severe } \\
\end{array}$ & Moderate & $\begin{array}{l}\text { Minor to } \\
\text { Moderate }\end{array}$ & Minor \\
\hline Faulting & Severe & & Moderate & & Minor \\
\hline Fracturing & Severe & & Moderate & & Minor \\
\hline Weathering & Severe & & Moderate & & Minor \\
\hline \multicolumn{6}{|c|}{ Subfactor Group 2: Soils } \\
\hline Soils & Noncohesive & & $\begin{array}{l}\text { Partly } \\
\text { Cohesive }\end{array}$ & & $\begin{array}{l}\text { Highly } \\
\text { Cohesive }\end{array}$ \\
\hline Soil Profile & $\begin{array}{l}\text { Minimal Soil } \\
\text { Profile }\end{array}$ & & $\begin{array}{l}\text { Some Soil } \\
\text { Profile }\end{array}$ & & $\begin{array}{l}\text { Well- } \\
\text { Developed } \\
\text { Soil Profile }\end{array}$ \\
\hline Soil Cover & $\begin{array}{l}\text { Much Bare } \\
\text { Soil in } \\
\text { Evidence }\end{array}$ & & $\begin{array}{l}\text { Some Bare } \\
\text { Soil in } \\
\text { Evidence }\end{array}$ & & $\begin{array}{l}\text { Little Bare } \\
\text { Soil in } \\
\text { Evidence }\end{array}$ \\
\hline $\begin{array}{l}\text { Clay } \\
\text { Colloids }\end{array}$ & $\begin{array}{l}\text { Few Clay } \\
\text { Colloids }\end{array}$ & & $\begin{array}{l}\text { Some Clay } \\
\text { Colloids }\end{array}$ & & $\begin{array}{l}\text { Many Clay } \\
\text { Colloids }\end{array}$ \\
\hline \multicolumn{6}{|c|}{ Subfactor Group 3: Channel Morphology } \\
\hline $\begin{array}{l}\text { Bedrock } \\
\text { Exposures }\end{array}$ & $\begin{array}{l}\text { Few } \\
\text { Segments in } \\
\text { Bedrock }\end{array}$ & & $\begin{array}{l}\text { Some } \\
\text { Segments } \\
\text { in Bedrock } \\
\end{array}$ & & $\begin{array}{l}\text { Many } \\
\text { Segments } \\
\text { in Bedrock } \\
\end{array}$ \\
\hline $\begin{array}{l}\text { Bank } \\
\text { Erosion }\end{array}$ & $\begin{array}{l}>30 \% \text { of } \\
\text { Banks } \\
\text { Eroding }\end{array}$ & & $\begin{array}{l}10-30 \% \text { of } \\
\text { Banks } \\
\text { Eroding }\end{array}$ & & $\begin{array}{l}<10 \% \text { of } \\
\text { Banks } \\
\text { Eroding }\end{array}$ \\
\hline $\begin{array}{l}\text { Bed and } \\
\text { Bank } \\
\text { Material }\end{array}$ & $\begin{array}{l}\text { Noncohesive } \\
\text { Bed and } \\
\text { Banks }\end{array}$ & & $\begin{array}{l}\text { Partly } \\
\text { Cohesive } \\
\text { Bed and } \\
\text { Banks }\end{array}$ & & $\begin{array}{l}\text { Highly } \\
\text { Cohesive } \\
\text { Bed and } \\
\text { Banks } \\
\end{array}$ \\
\hline Vegetation & $\begin{array}{l}\text { Poorly } \\
\text { Vegetated }\end{array}$ & & $\begin{array}{l}\text { Some } \\
\text { Vegetation }\end{array}$ & & $\begin{array}{l}\text { Much } \\
\text { Vegetation }\end{array}$ \\
\hline Headcutting & $\begin{array}{l}\text { Many } \\
\text { Headcuts }\end{array}$ & & $\begin{array}{l}\text { Few } \\
\text { Headcuts }\end{array}$ & & $\begin{array}{l}\text { No } \\
\text { Headcuts }\end{array}$ \\
\hline & & & & & (Continued \\
\hline
\end{tabular}


Table A3 (Concluded)

\begin{tabular}{||l|l|l|l|l|l||}
\hline \multicolumn{7}{|c|}{ A-T Subfactor } \\
\hline \hline \multicolumn{5}{|c|}{ Subfactor Group 4: Hill Slope Morphology } \\
\hline \hline \multicolumn{7}{|c|}{$\begin{array}{l}0.25 \\
\begin{array}{l}\text { Rills and } \\
\text { Gullies }\end{array}\end{array}$} & $\begin{array}{l}\text { Many and } \\
\text { Active }\end{array}$ & 0.20 & 0.15 & 0.10 & 0.05 \\
\hline $\begin{array}{l}\text { Mass } \\
\text { Movement }\end{array}$ & $\begin{array}{l}\text { Many Scars } \\
\text { Evident }\end{array}$ & Some Signs & & Few Signs \\
\hline $\begin{array}{l}\text { Debris } \\
\text { Deposits }\end{array}$ & $\begin{array}{l}\text { Many } \\
\text { Eroding } \\
\text { Deposits }\end{array}$ & $\begin{array}{l}\text { Few Signs } \\
\text { Evident }\end{array}$ & & $\begin{array}{l}\text { No Signs } \\
\text { Evident }\end{array}$ \\
\hline \hline
\end{tabular}




\begin{tabular}{|c|c|c|c|c|c|c|c|}
\hline \multicolumn{8}{|c|}{$\begin{array}{l}\text { Table A4 } \\
\text { Input Parameters for Los Angeles District Method }\end{array}$} \\
\hline Stream & $\begin{array}{l}\text { Event } \\
\text { years }\end{array}$ & $\begin{array}{l}\text { Drainage } \\
\text { Area } \\
\text { acres }\end{array}$ & $\begin{array}{l}\text { Relief } \\
\text { Ratio } \\
\text { ft/mile }\end{array}$ & $\begin{array}{l}\text { 1-hour } \\
\text { Point } \\
\text { Rainfall, in. }\end{array}$ & $\begin{array}{l}\text { NOAA } \\
\text { Fraction }\end{array}$ & $\begin{array}{l}1 \text {-hour } \\
\text { Rainfall } \\
* 100\end{array}$ & $\begin{array}{l}\text { Fire } \\
\text { Factor }\end{array}$ \\
\hline \multicolumn{8}{|c|}{ Equation 2} \\
\hline \multirow[t]{2}{*}{ Unnamed } & 100 & 864 & 1,651 & 2.50 & 0.99 & 248 & 3 \\
\hline & 2 & 864 & 1,651 & 0.91 & 0.99 & 90 & 6.5 \\
\hline \multirow{2}{*}{$\begin{array}{l}\text { Black Canyon } \\
\text { Creek }\end{array}$} & 100 & 1,651 & 662 & 2.50 & 0.98 & 245 & 3 \\
\hline & 2 & 1,651 & 662 & 0.91 & 0.98 & 90 & 6.5 \\
\hline \multirow{2}{*}{$\begin{array}{l}\text { Williams } \\
\text { Canyon Creek }\end{array}$} & 100 & 1,722 & 687 & 2.50 & 0.98 & 245 & 3 \\
\hline & 2 & 1.722 & 687 & 0.91 & 0.98 & 90 & 6.5 \\
\hline \multicolumn{8}{|c|}{ Equation 4} \\
\hline & & & & $\begin{array}{l}\text { Discharge } \\
\text { cfs }\end{array}$ & $\begin{array}{l}\text { Unit } \\
\text { Discharge } \\
\text { cfs/square } \\
\text { mile }\end{array}$ & & \\
\hline \multirow{2}{*}{$\begin{array}{l}\text { Sutherland } \\
\text { Creek }\end{array}$} & 100 & 3,302 & 1,004 & 1,090 & 211 & & 3 \\
\hline & 2 & 3,302 & 1,004 & 14 & 2.71 & & 6 \\
\hline \multicolumn{8}{|c|}{ Equation 5} \\
\hline \multirow[t]{2}{*}{ Ruxton Creek } & 100 & 7,712 & 1,131 & 2,049 & 170 & & 3 \\
\hline & 2 & 7,712 & 1,131 & 33 & 2.74 & & 6 \\
\hline \multicolumn{8}{|c|}{ Equation $6 / 7$} \\
\hline \multirow{2}{*}{$\begin{array}{l}\text { Fountain } \\
\text { Creek }\end{array}$} & 100 & 32,198 & 243 & 6,070 & 121 & & 3 \\
\hline & 2 & 32,198 & 243 & 139 & 2.76 & & 6 \\
\hline
\end{tabular}




\begin{tabular}{||l|l|l||}
\hline \multicolumn{2}{||l||}{$\begin{array}{l}\text { Table A5 } \\
\text { A-T Factor Determination }\end{array}$} \\
\hline \hline A-T Subfactor & Average Case & More Severe Case \\
\hline \hline Parent material & 0.15 & 0.15 \\
\hline Soils & 0.15 & 0.20 \\
\hline Channel morphology & 0.15 & 0.20 \\
\hline Hill slope morphology & 0.10 & 0.20 \\
\hline A-T factor & 0.55 & 0.75 \\
\hline \hline
\end{tabular}




\begin{tabular}{|c|c|c|c|c|c|}
\hline \multicolumn{6}{|c|}{$\begin{array}{l}\text { Table A6 } \\
\text { Factors Affecting Sediment Yield, PSIAC Method }\end{array}$} \\
\hline $\begin{array}{l}\text { Sediment } \\
\text { Yield } \\
\text { Levels }\end{array}$ & $\begin{array}{l}\text { A } \\
\text { Surface } \\
\text { Geology }\end{array}$ & $\begin{array}{l}\text { B } \\
\text { Soils }\end{array}$ & $\begin{array}{l}\text { C } \\
\text { Climate }\end{array}$ & $\begin{array}{l}\text { D } \\
\text { Runoff }\end{array}$ & $\begin{array}{l}\text { E } \\
\text { Topography }\end{array}$ \\
\hline High & $\begin{array}{l}(10) \\
\text { a. Marine } \\
\text { shales and } \\
\text { related } \\
\text { mudstones and } \\
\text { siltstones. }\end{array}$ & $\begin{array}{l}\text { (10) } \\
\text { a. Fine textured; } \\
\text { easily dispersed; } \\
\text { saline-alkaline; } \\
\text { high shrink- } \\
\text { swell } \\
\text { characteristics. } \\
\text { b. Single grain } \\
\text { silts and fine } \\
\text { sands }\end{array}$ & $\begin{array}{l}\text { (10) } \\
\text { a. Storms of } \\
\text { several days' } \\
\text { duration with } \\
\text { short periods } \\
\text { of intense } \\
\text { rainfall } \\
\text { b. Frequent } \\
\text { intense } \\
\text { convective } \\
\text { storms } \\
\text { c. Freeze-thaw } \\
\text { occurrence }\end{array}$ & $\begin{array}{l}\text { (10) } \\
\text { a. High peak } \\
\text { flows per unit } \\
\text { area } \\
\text { b. Large } \\
\text { volume of } \\
\text { flow per unit } \\
\text { area }\end{array}$ & $\begin{array}{l}\text { (20) } \\
\text { a. Steep upland } \\
\text { slopes (in excess } \\
\text { of } 30 \% \text { ); high } \\
\text { relief; little or no } \\
\text { floodplain } \\
\text { development }\end{array}$ \\
\hline \\
\hline Moderate & $\begin{array}{l}\text { (5) } \\
\text { a. Rocks of } \\
\text { medium } \\
\text { hardness } \\
\text { b. Moderately } \\
\text { weathered } \\
\text { c. Moderately } \\
\text { fractured }\end{array}$ & $\begin{array}{l}\text { (5) } \\
\text { a. Medium } \\
\text { textured soil } \\
\text { b. Occasional } \\
\text { rock fragments } \\
\text { c. Caliche layers }\end{array}$ & $\begin{array}{l}\text { (5) } \\
\text { a. Storms of } \\
\text { moderate } \\
\text { duration and } \\
\text { intensity } \\
\text { b. Infrequent } \\
\text { convective } \\
\text { storms }\end{array}$ & $\begin{array}{l}\text { (5) } \\
\text { a. Moderate } \\
\text { peak flows } \\
\text { b. Moderate } \\
\text { volume of } \\
\text { flow per unit } \\
\text { area }\end{array}$ & $\begin{array}{l}\text { (10) } \\
\text { a. Moderate } \\
\text { upland slopes } \\
\text { (less than } 20 \% \text { ) } \\
\text { b. Moderate fan } \\
\text { or floodplain } \\
\text { development }\end{array}$ \\
\hline \multicolumn{6}{|l|}{ ** } \\
\hline Low & $\begin{array}{l}\text { (0) } \\
\text { a. Massive, } \\
\text { hard } \\
\text { formations }\end{array}$ & $\begin{array}{l}\text { (0) } \\
\text { a. High } \\
\text { percentage of } \\
\text { rock fragments } \\
\text { b. Aggregated } \\
\text { clays } \\
\text { c. High in } \\
\text { organic matter }\end{array}$ & $\begin{array}{l}\text { (0) } \\
\text { a. Humid } \\
\text { climate with } \\
\text { rainfall of low } \\
\text { intensity } \\
\text { b. Precipitation } \\
\text { in form of } \\
\text { snow } \\
\text { c. Arid climate, } \\
\text { low- intensity } \\
\text { storms } \\
\text { d. Arid climate; } \\
\text { rare convective } \\
\text { storms }\end{array}$ & $\begin{array}{l}\text { (0) } \\
\text { a. Low peak } \\
\text { flows per unit } \\
\text { area } \\
\text { b. Low } \\
\text { volume of } \\
\text { runoff per } \\
\text { unit area } \\
\text { c. Rare runoff } \\
\text { events }\end{array}$ & $\begin{array}{l}\text { (0) } \\
\text { a. Gentle upland } \\
\text { slopes (less than } \\
5 \% \text { ) } \\
\text { b. Extensive allu- } \\
\text { vial plains }\end{array}$ \\
\hline & & & & & (Continued \\
\hline
\end{tabular}




\begin{tabular}{|c|c|c|c|c|}
\hline $\begin{array}{l}\text { Sediment Yield } \\
\text { Levels }\end{array}$ & $\begin{array}{l}\text { F } \\
\text { Ground } \\
\text { Cover }\end{array}$ & $\begin{array}{l}\text { G } \\
\text { Land Use }\end{array}$ & $\begin{array}{l}\text { H } \\
\text { Upland } \\
\text { Erosion }\end{array}$ & $\begin{array}{l}\text { I } \\
\text { Channel Erosion } \\
\text { and Sediment } \\
\text { Transport }\end{array}$ \\
\hline High & $\begin{array}{l}\text { (10) } \\
\text { Ground cover } \\
\text { does not exceed } \\
20 \% \\
\text { a. Vegetation } \\
\text { sparse; little or } \\
\text { no litter } \\
\text { b. No rock in } \\
\text { surface soil }\end{array}$ & $\begin{array}{l}\text { (10) } \\
\text { a. More than } 50 \% \\
\text { cultivated } \\
\text { b. Almost all of } \\
\text { area intensively } \\
\text { grazed } \\
\text { c. All of area } \\
\text { recently burned }\end{array}$ & $\begin{array}{l}\text { (25) } \\
\text { a. More than } 50 \% \\
\text { of the area } \\
\text { characterized by rill } \\
\text { and gully or } \\
\text { landslide erosion }\end{array}$ & $\begin{array}{l}\text { (25) } \\
\text { a. Eroding banks con- } \\
\text { tinuously or at } \\
\text { frequent intervals with } \\
\text { large depths and long } \\
\text { flow duration } \\
\text { b. Active headcuts } \\
\text { and degradation in } \\
\text { tributary channels }\end{array}$ \\
\hline \multicolumn{5}{|l|}{$\cdots$} \\
\hline Moderate & $\begin{array}{l}\text { (0) } \\
\text { Cover not } \\
\text { exceeding } 40 \% \\
\text { a. Noticeable } \\
\text { litter } \\
\text { b. If trees } \\
\text { present, under- } \\
\text { story not well } \\
\text { developed }\end{array}$ & $\begin{array}{l}\text { (0) } \\
\text { a. Less than } 25 \% \\
\text { cultivated } \\
\text { b. } 50 \% \text { or less } \\
\text { recently logged, } \\
\text { c. Less than } 50 \% \\
\text { intensively grazed } \\
\text { d. Ordinary road } \\
\text { and other } \\
\text { construction }\end{array}$ & $\begin{array}{l}\text { (10) } \\
\text { a. About } 25 \% \text { of } \\
\text { the area } \\
\text { characterized by rill } \\
\text { and gully or } \\
\text { landslide erosion } \\
\text { b. Wind erosion } \\
\text { with deposition in } \\
\text { stream channels }\end{array}$ & $\begin{array}{l}\text { (10) } \\
\text { a. Moderate flow } \\
\text { depths, medium flow } \\
\text { duration with } \\
\text { occasionally eroding } \\
\text { banks or bed }\end{array}$ \\
\hline \multicolumn{5}{|l|}{$\leftrightarrow$} \\
\hline Low & $\begin{array}{l}(-10) \\
\text { a. Area } \\
\text { completely pra- } \\
\text { tected by } \\
\text { vegetation, rock } \\
\text { fragments, litter. } \\
\text { Little } \\
\text { opportunity for } \\
\text { rainfall to reach } \\
\text { erodible material }\end{array}$ & $\begin{array}{l}(-10) \\
\text { a. No cultivation } \\
\text { b. No recent } \\
\text { logging } \\
\text { c. Low-intensity } \\
\text { grazing }\end{array}$ & $\begin{array}{l}\text { (0) } \\
\text { a. No apparent } \\
\text { signs of erosion }\end{array}$ & $\begin{array}{l}\text { (0) } \\
\text { a. Wide shallow } \\
\text { channels with flat } \\
\text { gradients, short flow } \\
\text { duration } \\
\text { b. Channels in massive } \\
\text { rocks, large boulders } \\
\text { or well vegetated } \\
\text { c. Artificially } \\
\text { controlled channels }\end{array}$ \\
\hline
\end{tabular}




\begin{tabular}{|c|c|c|c|c|c|c|}
\hline \multicolumn{7}{|c|}{$\begin{array}{l}\text { Table A7 } \\
\text { Assigned Ratings, PSIAC Method }\end{array}$} \\
\hline $\begin{array}{l}\text { Determining } \\
\text { Factor }\end{array}$ & $\begin{array}{l}\text { Un- } \\
\text { named } \\
\text { Creek }\end{array}$ & $\begin{array}{l}\text { Black } \\
\text { Canyon } \\
\text { Creek }\end{array}$ & $\begin{array}{l}\text { Williams } \\
\text { Canyon } \\
\text { Creek }\end{array}$ & $\begin{array}{l}\text { Sutherland } \\
\text { Creek }\end{array}$ & $\begin{array}{l}\text { Ruxton } \\
\text { Creek }\end{array}$ & $\begin{array}{l}\text { Fountain } \\
\text { Creek }\end{array}$ \\
\hline $\begin{array}{l}\text { A. Surface } \\
\text { Geology }\end{array}$ & 5 & 5 & 5 & 5 & 5 & 5 \\
\hline B. Soils & 2.5 & 2.5 & 2.5 & 2.5 & 2.5 & 2.5 \\
\hline C. Climate & 7.5 & 7.5 & 7.5 & 7.5 & 7.5 & 7.5 \\
\hline D. Runoff & 7.5 & 7.5 & 7.5 & 7.5 & 7.5 & 7.5 \\
\hline E. Topography & 20 & 10 & 17.5 & 20 & 20 & 12.5 \\
\hline F. Ground Cover & -7.5 & -7.5 & -7.5 & -7.5 & -7.5 & -7.5 \\
\hline G. Land Use & -10 & -10 & -10 & -10 & -10 & -10 \\
\hline $\begin{array}{l}\text { H. Upland } \\
\text { Erosion }\end{array}$ & 5 & 5 & 5 & 5 & 5 & 5 \\
\hline $\begin{array}{l}\text { I. Channel } \\
\text { Morphology and } \\
\text { Sediment } \\
\text { Transport }\end{array}$ & 15 & 15 & 15 & 15 & 15 & 15 \\
\hline Total Rating & 45.5 & 35 & 42.5 & 45 & 45 & 37.5 \\
\hline
\end{tabular}




\section{REPORT DOCUMENTATION PAGE}

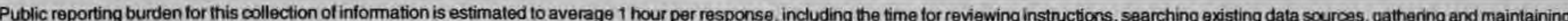

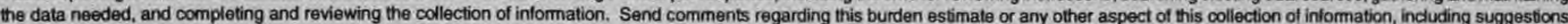

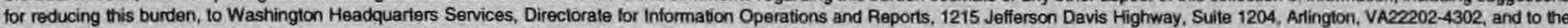
Office of Management and Budget, Paperwork Reduction Project (0704-0188), Washington, DC20503.

\begin{tabular}{|l|l|l|}
\hline 1. AGENCY USE ONLY (Leave blank) & $\begin{array}{c}\text { 2. REPORT DATE } \\
\text { July } 1995\end{array}$ & $\begin{array}{c}\text { 3. REPORT TYPE AND DATES COVERED } \\
\text { Final report }\end{array}$
\end{tabular}

4. TITLE AND SUBTITLE

Sediment Impact Assessment, Manitou Springs, Colorado

5. FUNDING NUMBERS

6. AUTHOR(S)

Ronald R. Copeland, Lisa C. Hubbard

7. PERFORMING ORGANIZATION NAME(S) AND ADDRESS(ES)

U.S. Army Engineer Waterways Experiment Station

3909 Halls Ferry Road, Vicksburg, MS 39180-6199

8. PERFORMING ORGANIZATION REPORT NUMBER

Technical Report HL-95-3

9.SPONSORING/MONITORING AGENCY NAME(S) AND ADDRESS(ES)

U.S. Army Engineer District, Albuquerque

10.SPONSORING/MONITORING

P.O. Box 1580, Albuquerque, NM 87103-1580 AGENCY REPORT NUMBER

\section{SUPPLEMENTARY NOTES}

Available from National Technical Information Service, 5285 Port Royal Road, Springfield, VA 22161.

12a.DISTRIBUTION/AVAILABILITY STATEMENT

12b.DISTRIBUTION CODE

Approved for public release; distribution is unlimited.

\section{ABSTRACT (Maximum 200 words)}

A sediment impact assessment was conducted for Fountain Creek in Manitou Springs, CO, as part of a reconnaissance level planning study. The purpose of the study was to identify the magnitude of sediment problems that might be associated with proposed flood-control projects, and to recommend appropriate sediment studies for the next level of planning study. The study employs the sediment budget approach to assess channel stability in the study reach. The potential for debris flows from tributary streams was evaluated. Total sediment yield estimates were made for preliminary sizing of debris basins and/or reservoirs. Recommendations for more detailed sediment studies were made.

\section{SUBJECT TERMS}

Flood protection

SAM

Sediment assessment
Sediment yield

Sedimentation
15.NUMBER OF PAGES

62

16.PRICE CODE

\section{SECURITY CLASSIFICATION OF REPORT \\ 18.SECURITY CLASSIFICATION OF THIS PAGE}

19.SECURITY CLASSIFICATION OF ABSTRACT

\section{UNCLASSIFIED UNCLASSIFIED}

Standard Form 298 (Rev. 2-89) Prescribed by ANSI Std. 239-18 298-102 